Article

\title{
Ancient Melt Depletion and Metasomatic History of the Subduction Zone Mantle: Osmium Isotope Evidence of Peridotites from the Yap Trench, Western Pacific
}

\author{
Ling Chen ${ }^{1,2}$, Limei Tang ${ }^{1,2, *}$, Xiaohu $\mathrm{Li}^{1,2}$, Jie Zhang ${ }^{1,2}, *$, Wei Wang ${ }^{1,2}{ }^{1}$, Zhenggang $\mathrm{Li}^{1,2}$, \\ Hao Wang ${ }^{1,2}$, Xichang $\mathrm{Wu}^{1,2}$ and Fengyou $\mathrm{Chu}{ }^{1,2}$ \\ 1 Key Laboratory of Submarine Geosciences, State Oceanic Administration, Hangzhou 310012, China; \\ chenling@sio.org.cn (L.C.); xhli@sio.org.cn (X.L.); 11638010@zju.edu.cn (W.W.); lizg@sio.org.cn (Z.L.); \\ wanghao@sio.org.cn (H.W.); xichangwu@yeah.net (X.W.); fengyouchusio@163.com (F.C.) \\ 2 Second Institute of Oceanography, Ministry of Natural Resources, Hangzhou 310012, China \\ * Correspondence: tanglm@sio.org.cn (L.T.); zhangjie@sio.org.cn (J.Z.); \\ Tel.: +86-571-81963165 (L.T.); +86-571-81969133 (J.Z.)
}

Received: 16 September 2019; Accepted: 18 November 2019; Published: 20 November 2019

check for updates

\begin{abstract}
Highly depleted peridotites from the Yap Trench in the western Pacific Ocean have been studied for Re-Os elements and Re-Os isotopes. These peridotites have a low Re-Os content and variable ${ }^{187} \mathrm{Os} /{ }^{188} \mathrm{Os}$ ratios $(0.12043-0.14867)$. The highest ${ }^{187} \mathrm{Os} /{ }^{188} \mathrm{Os}$ ratio is far higher than that of the primitive upper mantle and the lowest ${ }^{187} \mathrm{Os} /{ }^{188} \mathrm{Os}$ ratio is comparable to the most unradiogenic ${ }^{187} \mathrm{Os} /{ }^{188} \mathrm{Os}$ ratio $(0.11933)$ discovered in subduction zone peridotites. The suprachondritic ${ }^{187} \mathrm{Os} /{ }^{188} \mathrm{Os}$ ratios of the Yap Trench peridotites results from modification of the mantle wedge by slab-derived fluid and melt. This is consistent with the observation that high ${ }^{187} \mathrm{Os} /{ }^{188} \mathrm{Os}$ ratios generally occur in oceanic peridotites with low Os content $(<2 \mathrm{ppb})$ since Os may be reduced during late processes such as fluid alteration and melt refertilization. The sub-chondritic ${ }^{187} \mathrm{Os} /{ }^{188} \mathrm{Os}$ ratios of the Yap Trench peridotites correspond to a Re depletion age of 0.24-1.16 billion years, which means that these peridotites represent old mantle residue of ancient melting events. This ancient melting, combined with probable back-arc melting and forearc melting during subduction initiation, indicates that the Yap Trench mantle has a complex evolutionary history. The amount of old mantle residue in the oceanic asthenosphere was underestimated because the ${ }^{187} \mathrm{Os} /{ }^{188} \mathrm{Os}$ ratio in mantle peridotites is elevated during late processes. Therefore, old depleted mantle fragments may contribute substantially to the chemical heterogeneity of the oceanic mantle.
\end{abstract}

Keywords: ${ }^{187} \mathrm{Os} /{ }^{188} \mathrm{Os}$; peridotite; subduction zone; Yap Trench; melt depletion

\section{Introduction}

As ${ }^{187}$ Re decays to ${ }^{187}$ Os with a half-life of about 42 billion years (Ga) [1], the ${ }^{187} \mathrm{Os} /{ }^{188}$ Os ratios of basaltic rock and mantle residue diverges. Therefore, the ${ }^{187} \mathrm{Re}-{ }^{187}$ Os system in mantle-derived rock is widely used for detecting mantle melting and post-melting processes, which are essential for constraining the geochemical evolution of the oceanic mantle. During mantle melting, Os behaves as a compatible element, whereas Re is a moderately incompatible element with a bulk partition coefficient similar to that of $\mathrm{Al}[2,3]$. Thus, the residual peridotites will be depleted in Re and evolve to sub-chondritic ${ }^{187} \mathrm{Os} /{ }^{188} \mathrm{Os}$. In contrast, Re-enriched basaltic rock will develop highly suprachondritic ${ }^{187} \mathrm{Os} /{ }^{188} \mathrm{Os}[3-5]$. For example, mid-ocean ridge basalts generally have higher ${ }^{87} \mathrm{Os} /{ }^{188} \mathrm{Os}$ ratios $(0.125-0.23)$ relative to abyssal peridotites $(0.12-0.13)$ [6]. In addition, the ${ }^{187} \mathrm{Os} /{ }^{188} \mathrm{Os}$ ratio in seawater 
$(\sim 1)$ is much higher than that in the bulk Earth $(\sim 0.127)$ [7]; therefore, apart from mantle melting, the secondary processes also play an important role in shaping the Os isotope composition of the melting residue, resulting in suprachondritic ${ }^{187} \mathrm{Os} /{ }^{188} \mathrm{Os}$ ratios. However, unradiogenic ${ }^{187} \mathrm{Os} /{ }^{188} \mathrm{Os}$ ratios are widely reported in abyssal peridotites from mid-ocean ridges [8-12]; these peridotites were thought to be inherited from ancient mantle melting events given an oldest depleted age of $\sim 2 \mathrm{Ga}$ [10]. This means that instead of being obscured by secondary processes, ancient melting signatures can survive on long timescales in the oceanic upper mantle. Additional evidence for ancient melting in the oceanic mantle was presented by peridotite mantle xenoliths from oceanic islands, which indicates that mantle plumes also contain components from an ancient recycled lithospheric mantle [13]. With respect to the subduction zone, unradiogenic ${ }^{187} \mathrm{Os} /{ }^{188} \mathrm{Os}$ ratios were frequently found in ophiolites and interpreted as representative of the ancient oceanic lithosphere [14-16]. By contrast, ancient melting evidence in peridotites from modern subduction zones is relatively scarce; this is probably due to the influence of slab-derived fluids or melts, as revealed by the peridotite xenoliths from convergent plate margins [17]. However, serpentinized peridotites collected from the Izu-Bonin-Mariana forearc have unradiogenic ${ }^{187} \mathrm{Os} /{ }^{188} \mathrm{Os}$ ratios that provide a model age of $1.2 \mathrm{Ga}$, which suggests that ancient depleted mantle can be preserved in modern subduction zones even though it has undergone strong metasomatism [18]. These observations indicate that instead of being homogenized by convective stirring chemical heterogeneities in oceanic mantle occur in different tectonic environments. Mantle peridotites from subduction zones mostly have experienced complex melting histories and were modified by slab-derived materials, which makes it difficult to constrain the primary signature of the asthenosphere. The Re-Os isotope system can provide unique perspective into both the nature of melt extraction and the influence of post-melting processes. In this paper, the Re-Os isotopes of peridotites from the Yap subduction zone were studied to constrain the effect of subduction-related modification and the nature of asthenospheric mantle.

\section{Materials and Methods}

\subsection{Geological Setting}

The Yap Trench is located at the junction of the Philippine Sea Plate, the Pacific Plate, and the Caroline Plate (Figure 1). The Mariana Trench, the Palau Trench, and the Caroline Ridge are adjacent to the Yap Trench from the north, southwest, and east, respectively. Along the Yap Trench, the Pacific and Caroline plates subduct below the Philippine Sea Plate at an estimated rate of 0 to $6 \mathrm{~mm} /$ year [19]. The Yap Trench is one of the deepest trenches on Earth, with a deepest water depth of $8527 \mathrm{~m}$ [20]. The subduction processes, magmatism, and tectonic activity of the Yap Trench have been studied to investigate the dynamic mechanisms and mantle evolution of the Yap subduction system [20-27]. The results have shown that the Yap Trench has some features in common with other subduction zones in the western Pacific, such as a trench-arc-basin system and a great axial depth [22,23]. Moreover, some characteristics of the Yap Trench are distinct from other trenches, for example: a very short distance between the trench axis and the island $\operatorname{arc}(\sim 50 \mathrm{~km})$, an intersection with the Mariana Trench at a nearly perpendicular angle, a collision with the Caroline Ridge (ESE-WNW trending) from the east, a notable lack of arc volcanism [28,29], little seismicity, and a lack of deep earthquakes [23].

There are complex tectonic morphostructures in the subducting Caroline Plate, such as the Caroline Ridge, the West Caroline Rise, the Sorol Trough, and numerous horsts and grabens [20,25,30,31], thus the tectonic erosion of the overlying plate may be enhanced. As a result, more slab-derived materials were transported into the mantle wedge. In addition, asthenospheric mantle underneath the Philippine Sea Plate is inferred to flow outward through the subducting slab along the southern Mariana-Yap-Palau Trench [32]. These features indicate that the upper mantle beneath the Yap Trench system may have experienced complex evolutionary history, which may have a significant influence on the geochemistry of mantle-derived rocks. Hawkins and Batiza (1977) [29] have shown that the basement of the Yap arc is composed of ultramafic to mafic metamorphic rock. The peridotites and volcanic rocks from the 
north Yap Escarpment and the Yap Trench were interpreted as subduction-related rocks [24,26]. By contrast, a complex evolutionary history including mantle melting at the initial stage of subduction was proposed to explain the highly depleted Yap Trench peridotites [27].

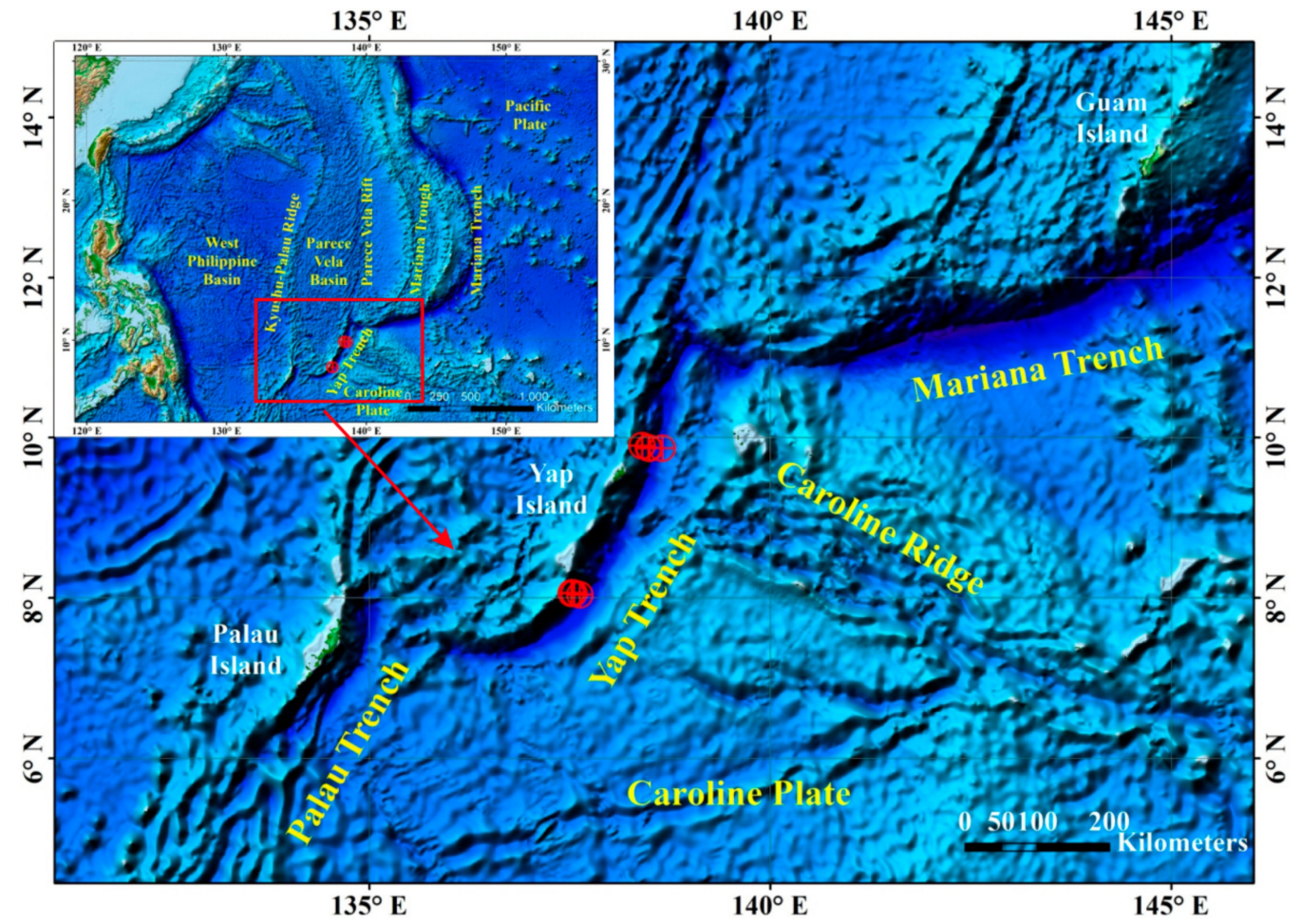

Figure 1. Bathymetry and tectonic features of the studied area. Red box shows the location of the Yap Trench. Sampling locations (red circles) for Dive 112 (northern Yap Trench) and JL 149 (southern Yap Trench) are shown.

\subsection{Samples and Analytical Methods}

Peridotite samples in this study were collected from the northern and southern parts of the Yap Trench using the Chinese manned submersible, Jiaolong (Figure 1). Six samples from the northern Yap Trench were collected during cruise DY125-37 on Dive 112. Two samples from the southern Yap Trench were collected during cruise DY125-38 on Dive 149. Petrographic characteristics and elemental data from the northern Yap Trench samples have been reported by Chen et al. (2019) [27]. In this study, we report new Re-Os elements and Re-Os isotope composition of the Yap Trench peridotites and new major and trace element compositions of the samples from the southern Yap Trench. All of the Yap Trench samples have experienced varying degrees of seafloor weathering and serpentinization. Based on the content of loss on ignition (LOI), the calculated degree of serpentinization is $71.9-78.1 \%$ $\left(\mathrm{Serp} \%=100 \times \mathrm{LOI} / \mathrm{PM}\left(\mathrm{H}_{2} \mathrm{O}\right), \mathrm{PM}\left(\mathrm{H}_{2} \mathrm{O}\right)=0.18 \%\right.$; PM: primitive mantle) [33]. The surfaces of the peridotite samples were cut off to remove any obvious alteration materials. Then, the selected samples were crushed in agate mortars to powders of 200 mesh size for analysis.

The whole-rock major and trace element analysis was performed at Wuhan Sample Solution Analytical Technology Co., Ltd., Wuhan, China. The major elements were analyzed by X-ray fluorescence (XRF); the analytical precision was better than $\pm 2-5 \%$. Whole-rock trace element analysis was conducted using an Agilent 7700e inductively coupled plasma mass spectrometry (ICP-MS) at Wuhan Sample Solution Analytical Technology Co., Ltd., Wuhan, China. The detailed sample-digesting procedure was as follows: (1) sample powder (200 mesh) was placed in an oven at $105^{\circ} \mathrm{C}$ for drying for $12 \mathrm{~h}$; (2) $50 \mathrm{mg}$ of sample powder was accurately weighed and placed in a Teflon bomb; (3) $1 \mathrm{~mL}$ $\mathrm{HNO}_{3}$ and $1 \mathrm{~mL} \mathrm{HF}$ were slowly added into the Teflon bomb; (4) the Teflon bomb was put in a stainless 
steel pressure jacket and heated to $190^{\circ} \mathrm{C}$ in an oven for $>24 \mathrm{~h}$; (5) after cooling, the Teflon bomb was opened, placed on a hotplate at $140{ }^{\circ} \mathrm{C}$ and evaporated to incipient dryness; $1 \mathrm{~mL} \mathrm{HNO}$ was then added, and the sample was evaporated to dryness again; (6) $1 \mathrm{~mL}$ of $\mathrm{HNO}_{3}, 1 \mathrm{~mL}$ of Milli-Q water, and $1 \mathrm{~mL}$ of internal standard solution of $1 \mathrm{ppm}$ In were added, and the Teflon bomb was resealed and placed in the oven at $190^{\circ} \mathrm{C}$ for $>12 \mathrm{~h}$; (7) finally, the solution was transferred to a polyethylene bottle and diluted to $100 \mathrm{~g}$ through the addition of $2 \% \mathrm{HNO}_{3}$.

Re-Os element and isotope compositions were performed at the State Key Laboratory of Isotope Geochemistry, Guangzhou Institute of Geochemistry, Chinese Academy of Sciences in Guangzhou, China. The Carius tube digestion technique was used for Re-Os chemistry [34]. About 0.5-2 g of each powdered sample was digested and equilibrated with ${ }^{185} \mathrm{Re}$ - and ${ }^{190} \mathrm{Os}$-enriched spikes in reverse aqua regia $\left(7.5 \mathrm{~mL}\right.$ concentrated $\mathrm{HNO}_{3}+2.5 \mathrm{~mL}$ concentrated $\left.\mathrm{HCl}\right)$ for $24 \mathrm{~h}$ at $240{ }^{\circ} \mathrm{C}$ in sealed Carius tubes. Os was extracted by solvent extraction into $\mathrm{CCl}_{4}$ and back-extracted into concentrated $\mathrm{HBr}$, with subsequent cleanup by microdistillation. The Re fraction was separated and purified using anion column chromatography.

Mass spectrometry procedures for the Os are given in Li et al. (2015a) [34]. Os was loaded onto $\mathrm{Pt}$ filaments and measured as $\mathrm{OsO}_{3}$ ions via negative-thermal ionization mass spectrometry (N-TIMS, Thermo Fisher Scientific, Waltham, MA, USA) using the electron multiplier mode on a Thermo-Finnigan Triton. Repeated analyses of the Os standard solution (Merck Chemical AA standard solution) yield a mean ${ }^{187} \mathrm{Os} /{ }^{188}$ Os value of $0.12042 \pm 0.00027(2 \mathrm{SD}, n=6)$ for the period of analysis. These values are in good agreement with a value of $0.12022 \pm 0.00020(2 \mathrm{SD}, n=14)$ measured on the same mass spectrometer in Faraday cup mode [35].

The Re mass fraction was analyzed using inductively coupled plasma mass spectrometry (Thermo Elemental X2 Series, Thermo Fisher Scientific, Waltham, MA, USA). A conventional low-volume quartz impact bead spray chamber with a Peltier cooled $\left({ }^{\circ} \mathrm{C}\right)$ and a $0.4 \mathrm{~mL} \mathrm{~min}^{-1}$ borosilicate nebulizer (MicroMist GE) was used in the determinations. Ion lens settings, nebulizer gas flow rate, and torch position were optimized daily using a $10 \mathrm{ng} \mathrm{mL}^{-1}$ tuning In-Ce mixture standard solution in order to obtain high instrumental sensitivity and low oxide production levels. A peristaltic pump was not used, as free aspiration of the nebulizer provided better signal stability. The details of the measurements are given in $\mathrm{Li}$ et al. (2014) [36]. Total procedural blanks were $0.45 \pm 0.04 \mathrm{pg}(1 \sigma, n=3)$ with an ${ }^{187} \mathrm{Os} /{ }^{188} \mathrm{Os}$ ratio of $0.284 \pm 0.025(1 \sigma, n=3)$ on average for Os and $5.1 \pm 0.9 \mathrm{pg}(1 \sigma, n=3)$ for Re. All data were corrected for the procedural blank for each analytical batch. Blank contributions were generally insignificant. The average values of the Re-Os isotope for basaltic reference material BIR-1 are in good agreement with published data [37].

\section{Results}

\subsection{Major and Trace Elements}

Whole-rock major and trace elements of the studied peridotites are presented in Table 1. Major elements of the Yap Trench peridotites are generally plotted along a composition trend defined by the abyssal peridotites and the forearc mantle peridotites (Figure 2). The Yap Trench peridotites and the peridotites from the Izu-Bonin-Mariana (IBM) forearc have higher $\mathrm{MgO}$ contents and lower $\mathrm{Al}_{2} \mathrm{O}_{3}$ and $\mathrm{CaO}$ contents than those of the abyssal peridotites (Figure $2 \mathrm{~b}, \mathrm{c}$ ). Compared with the IBM forearc mantle peridotites, the Yap Trench peridotites have extremely low $\mathrm{CaO}$ and relatively lower $\mathrm{Al}_{2} \mathrm{O}_{3}$. In the $\mathrm{Al}_{2} \mathrm{O}_{3} / \mathrm{SiO}_{2}$ versus $\mathrm{MgO} / \mathrm{SiO}_{2}$ diagram (Figure $2 \mathrm{~d}$ ), the oceanic peridotites define a trend parallel to the terrestrial array, and the forearc mantle peridotites are plotted on the high $\mathrm{MgO} / \mathrm{SiO}_{2}$ and low $\mathrm{Al}_{2} \mathrm{O}_{3} / \mathrm{SiO}_{2}$ ends. Two samples from the southern part of the Yap Trench have the most extreme compositions within the Yap Trench peridotites, which correspond to the most depleted and most fertile ends of the composition trend, respectively (Figure 2). 
Table 1. Major element (wt. \%) and trace element (ppm) concentrations in the bulk-rock peridotites.

\begin{tabular}{|c|c|c|c|c|c|c|c|c|}
\hline Station & \multicolumn{2}{|c|}{ Dive112-S04 } & \multicolumn{2}{|c|}{ Dive112-S05 } & \multicolumn{2}{|c|}{ Dive112-S08 } & 38III-Yap-JL149-S27 & 38III-Yap-JL149-S03 \\
\hline Longitude & \multicolumn{2}{|c|}{$138^{\circ} 29^{\prime} 46^{\prime \prime} \mathrm{E}$} & \multicolumn{2}{|c|}{$138^{\circ} 29^{\prime} 38^{\prime \prime} \mathrm{E}$} & \multicolumn{2}{|c|}{$138^{\circ} 28^{\prime} 44^{\prime \prime} \mathrm{E}$} & $137^{\circ} 32^{\prime} 53^{\prime \prime} \mathrm{E}$ & $137^{\circ} 33^{\prime} 14^{\prime \prime} \mathrm{E}$ \\
\hline Latitude & \multicolumn{2}{|c|}{$9^{\circ} 51^{\prime} 56^{\prime \prime} \mathrm{N}$} & \multicolumn{2}{|c|}{$9^{\circ} 51^{\prime} 57^{\prime \prime} \mathrm{N}$} & \multicolumn{2}{|c|}{$9^{\circ} 52^{\prime} 8^{\prime \prime} \mathrm{N}$} & $8^{\circ} 3^{\prime} 21^{\prime \prime} \mathrm{N}$ & $8^{\circ} 3^{\prime} 18^{\prime \prime} \mathrm{N}$ \\
\hline Sample ID & Dive112-S04-1 ${ }^{*}$ & Dive112-S04-2* & Dive112-S05-1* & Dive112-S05-2 & Dive112-S08-1 ${ }^{*}$ & Dive112-S08-2* & 38III-Yap-JL149-S27-1 & 38III-Yap-JL149-S03-1 \\
\hline \multicolumn{9}{|c|}{ Major element (wt. \%) } \\
\hline $\mathrm{SiO}_{2}$ & 44.96 & 44.95 & 45.81 & 45.72 & 45.95 & 46.15 & 46.12 & 45.59 \\
\hline $\mathrm{TiO}_{2}$ & 0.01 & 0.01 & - & - & - & - & 0.04 & - \\
\hline $\mathrm{Al}_{2} \mathrm{O}_{3}$ & 0.31 & 0.33 & 0.64 & 0.65 & 0.36 & 0.47 & 1.62 & 0.08 \\
\hline $\mathrm{TFe}_{2} \mathrm{O}_{3}$ & 8.96 & 9.01 & 7.69 & 7.67 & 7.5 & 7.53 & 8.76 & 9.02 \\
\hline $\mathrm{MnO}$ & 0.15 & 0.15 & 0.09 & 0.09 & 0.06 & 0.06 & 0.12 & 0.11 \\
\hline $\mathrm{MgO}$ & 44.38 & 44.44 & 44.98 & 44.66 & 45.46 & 45.37 & 42.97 & 44.67 \\
\hline $\mathrm{CaO}$ & 0.07 & 0.06 & 0.05 & 0.05 & 0.04 & 0.04 & 0.32 & 0.06 \\
\hline $\mathrm{Na}_{2} \mathrm{O}$ & 0.06 & 0.07 & 0.03 & 0.03 & 0.02 & 0.02 & 0.15 & 0.26 \\
\hline $\mathrm{K}_{2} \mathrm{O}$ & 0.01 & 0.01 & 0.01 & - & - & 0.01 & 0.02 & 0.01 \\
\hline $\mathrm{P}_{2} \mathrm{O}_{5}$ & 0.04 & 0.04 & 0.02 & 0.02 & 0.01 & 0.01 & 0.01 & 0.03 \\
\hline Sum & 98.94 & 99.05 & 99.32 & 98.89 & 99.4 & 99.66 & 100.12 & 99.85 \\
\hline LOI & 13.16 & 13.34 & 14.06 & 13.73 & 12.95 & 13 & 12.38 & 12.98 \\
\hline \multicolumn{9}{|c|}{ Trace element (ppm) } \\
\hline $\mathrm{Sc}$ & 3.89 & 3.81 & 6.1 & 6.07 & 6.06 & & 9.28 & 3.83 \\
\hline $\mathrm{Ti}$ & 34.37 & 32.57 & 7.07 & 6.24 & 5.71 & & - & - \\
\hline $\mathrm{V}$ & 31.66 & 31.69 & 34.08 & 32.5 & 34.65 & & 39.28 & 23.5 \\
\hline $\mathrm{Cr}$ & 2196 & 2466 & 3280 & 3011 & 2763 & & 2564 & 2639 \\
\hline Co & 97.65 & 97.61 & 72.95 & 71.79 & 88.73 & & 95.16 & 101.01 \\
\hline $\mathrm{Ni}$ & 2244 & 2212 & 2247 & 2207 & 2305 & & 2108 & 2133 \\
\hline $\mathrm{Cu}$ & 5.84 & 5.68 & 2.96 & 2.69 & 1.01 & & 9.53 & 1.39 \\
\hline $\mathrm{Zn}$ & 48.89 & 49.59 & 36.11 & 34.95 & 43.85 & & 40.59 & 33.44 \\
\hline Cs & 0.0015 & 0.001 & 0.0037 & 0.0042 & 0.0029 & & 0.0477 & 0.0094 \\
\hline $\mathrm{Rb}$ & 0.0807 & 0.067 & 0.1069 & 0.1059 & 0.0908 & & 0.5324 & 0.1775 \\
\hline $\mathrm{Ba}$ & 1.5346 & 1.6085 & 0.6862 & 0.5894 & 0.597 & & 2.2607 & 8.6628 \\
\hline Th & 0.02 & 0.0197 & 0.0008 & 0.0008 & 0.0024 & & 0.034 & 0.002 \\
\hline $\mathrm{U}$ & 0.8859 & 0.8836 & 0.6551 & 0.6856 & 0.5293 & & 0.0665 & 0.7195 \\
\hline $\mathrm{Nb}$ & 0.1811 & 0.1693 & 0.019 & 0.0217 & 0.0076 & & 0.036 & 0.0085 \\
\hline $\mathrm{Ta}$ & 0.0072 & 0.0065 & 0.0146 & 0.0135 & 0.0063 & & 0.011 & 0.0014 \\
\hline $\mathrm{La}$ & 0.1728 & 0.1844 & 0.0404 & 0.0376 & 0.0268 & & 0.0982 & 0.0335 \\
\hline
\end{tabular}


Table 1. Cont.

\begin{tabular}{|c|c|c|c|c|c|c|c|c|}
\hline Station & \multicolumn{2}{|c|}{ Dive112-S04 } & \multicolumn{2}{|c|}{ Dive112-S05 } & \multicolumn{2}{|c|}{ Dive112-S08 } & 38III-Yap-JL149-S27 & 38III-Yap-JL149-S03 \\
\hline Longitude & \multicolumn{2}{|c|}{$138^{\circ} 29^{\prime} 46^{\prime \prime} \mathrm{E}$} & \multicolumn{2}{|c|}{$138^{\circ} 29^{\prime} 38^{\prime \prime} \mathrm{E}$} & \multicolumn{2}{|c|}{$138^{\circ} 28^{\prime} 44^{\prime \prime} \mathrm{E}$} & $137^{\circ} 32^{\prime} 53^{\prime \prime} \mathrm{E}$ & $137^{\circ} 33^{\prime} 14^{\prime \prime} \mathrm{E}$ \\
\hline Latitude & \multicolumn{2}{|c|}{$9^{\circ} 51^{\prime} 56^{\prime \prime} \mathrm{N}$} & \multicolumn{2}{|c|}{$9^{\circ} 51^{\prime} 57^{\prime \prime} \mathrm{N}$} & \multicolumn{2}{|c|}{$9^{\circ} 52^{\prime} 8^{\prime \prime} \mathrm{N}$} & $8^{\circ} 3^{\prime} 21^{\prime \prime} \mathrm{N}$ & $8^{\circ} 3^{\prime} 18^{\prime \prime} \mathrm{N}$ \\
\hline Sample ID & Dive112-S04-1 ${ }^{*}$ & Dive112-S04-2* & Dive112-S05-1* & Dive112-S05-2 $^{*}$ & Dive112-S08-1* & Dive112-S08-2* & 38III-Yap-JL149-S27-1 & 38III-Yap-JL149-S03-1 \\
\hline $\mathrm{Ce}$ & 0.3122 & 0.3013 & 0.0265 & 0.0239 & 0.0189 & & 0.2895 & 0.0313 \\
\hline $\mathrm{Pb}$ & 0.0987 & 0.0913 & 0.1756 & 0.1816 & 0.3971 & & 0.2169 & 0.0339 \\
\hline $\operatorname{Pr}$ & 0.0375 & 0.0343 & 0.008 & 0.0085 & 0.0043 & & 0.036 & 0.0063 \\
\hline $\mathrm{Sr}$ & 4.72 & 4.51 & 2.39 & 2.35 & 1.55 & & 4.55 & 6.12 \\
\hline $\mathrm{Nd}$ & 0.1247 & 0.1358 & 0.0443 & 0.0416 & 0.0193 & & 0.1478 & 0.0436 \\
\hline $\mathrm{Zr}$ & 1.5174 & 1.8269 & 0.3524 & 0.5259 & 0.4541 & & 1.2321 & 0.0702 \\
\hline Hf & 0.0135 & 0.0213 & 0.0083 & 0.0119 & 0.013 & & 0.0487 & 0.0017 \\
\hline $\mathrm{Sm}$ & 0.023 & 0.0269 & 0.0064 & 0.0087 & 0.0045 & & 0.0599 & 0.0165 \\
\hline $\mathrm{Eu}$ & 0.0092 & 0.0093 & 0.007 & 0.0052 & 0.0017 & & 0.0314 & 0.0018 \\
\hline $\mathrm{Gd}$ & 0.0323 & 0.02 & 0.0138 & 0.0144 & 0.0032 & & 0.1088 & 0.0065 \\
\hline $\mathrm{Tb}$ & 0.0049 & 0.0045 & 0.0022 & 0.002 & 0.0006 & & 0.0505 & 0.0003 \\
\hline Dy & 0.0265 & 0.0279 & 0.0125 & 0.0106 & 0.0025 & & 0.1424 & 0.0054 \\
\hline Ho & 0.0064 & 0.008 & 0.0037 & 0.0027 & 0.0009 & & 0.0354 & 0.003 \\
\hline $\mathrm{Er}$ & 0.0242 & 0.0186 & 0.0138 & 0.0112 & 0.0045 & & 0.1135 & 0.0067 \\
\hline $\mathrm{Tm}$ & 0.003 & 0.0037 & 0.0022 & 0.0017 & 0.0008 & & 0.0201 & 0.0018 \\
\hline $\mathrm{Y}$ & 0.2175 & 0.2057 & 0.1745 & 0.1957 & 0.0646 & & 0.9621 & 0.1281 \\
\hline $\mathrm{Yb}$ & 0.0284 & 0.029 & 0.0165 & 0.0139 & 0.0069 & & 0.1336 & 0.0109 \\
\hline $\mathrm{Lu}$ & 0.006 & 0.0063 & 0.0024 & 0.0026 & 0.0019 & & 0.0488 & 0.0017 \\
\hline
\end{tabular}

*: Major and trace element data from Chen et al. (2019) [27]. LOI: Loss on ignition. Major element concentrations have been recalculated on an LOI-free basis. 

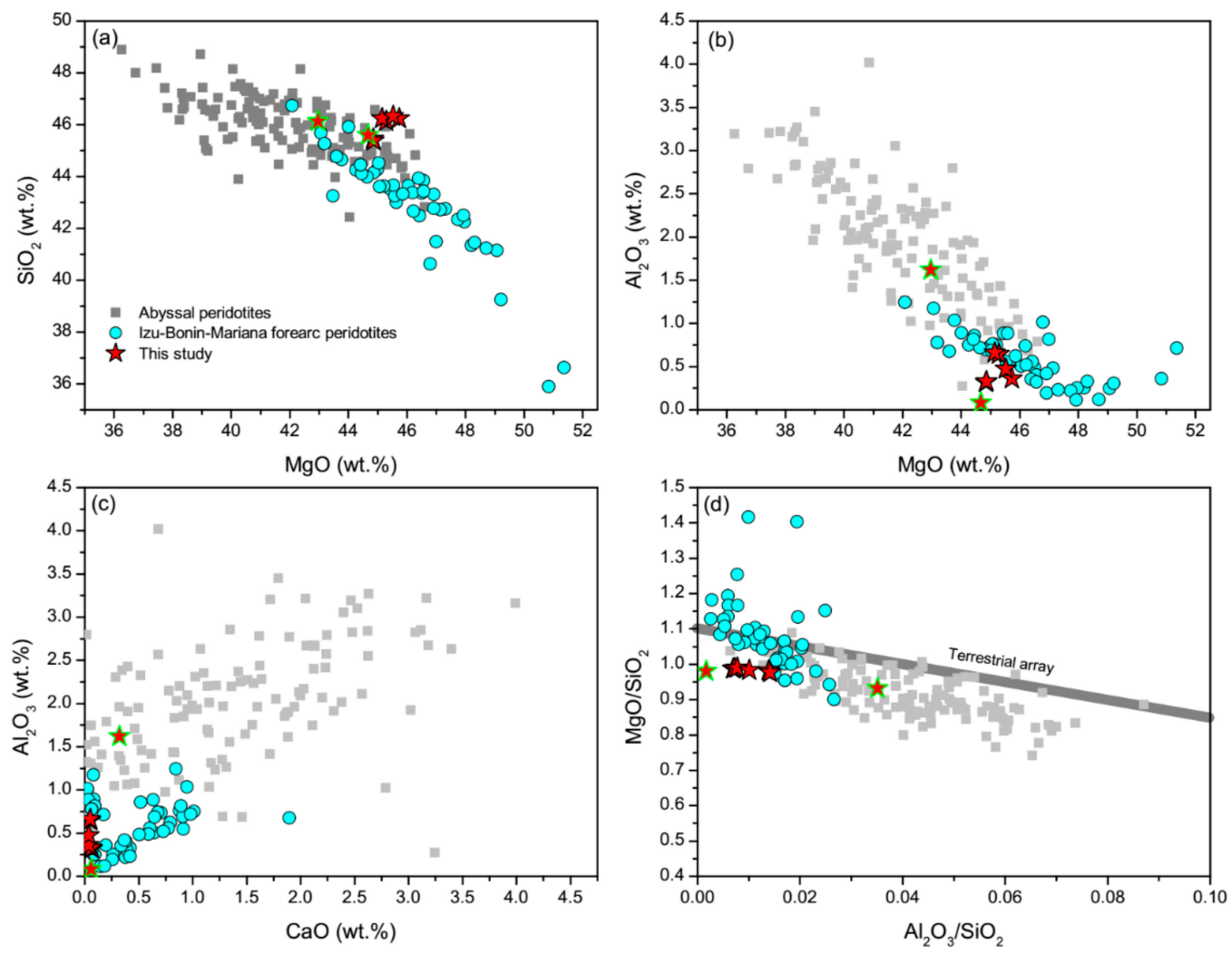

Figure 2. Plots of $\mathrm{MgO}$ versus (a) $\mathrm{SiO}_{2}$ and (b) $\mathrm{Al}_{2} \mathrm{O}_{3}$, (c) $\mathrm{CaO}$ versus $\mathrm{Al}_{2} \mathrm{O}_{3}$, and (d) $\mathrm{Al}_{2} \mathrm{O}_{3} / \mathrm{SiO}_{2}$ versus $\mathrm{MgO} / \mathrm{SiO}_{2}$ of the studied Yap Trench peridotites (stars). Samples from the southern Yap Trench are shown by stars with green border. Concentrations have been recalculated to $100 \%$ on a loss on ignition (LOI)-free basis. The abyssal peridotites [38] and peridotites from the Izu-Bonin-Mariana forearc $[39,40]$ are shown for comparison. The thick gray line in (d) represents the terrestrial array [41].

The Yap Trench peridotites show light rare earth element (LREE)-rich patterns in the chondrite-normalized diagram (Figure 3a). Sample JL149-S27-1 from the southern Yap Trench has a heavy rare earth element (HREE) content comparable to the average value of abyssal peridotites, while other samples have HREE contents similar to that of peridotites from the IBM forearc, which is plotted outside the HREE field of the abyssal peridotites. In the trace elements spider diagram (Figure $3 \mathrm{~b}$ ), the Yap Trench peridotites show a positive peak in $\mathrm{Ba}, \mathrm{U}$, and $\mathrm{Sr}$ with respect to the adjacent elements. In contrast, Ti shows negative anomalies in samples from the northern Yap Trench. 

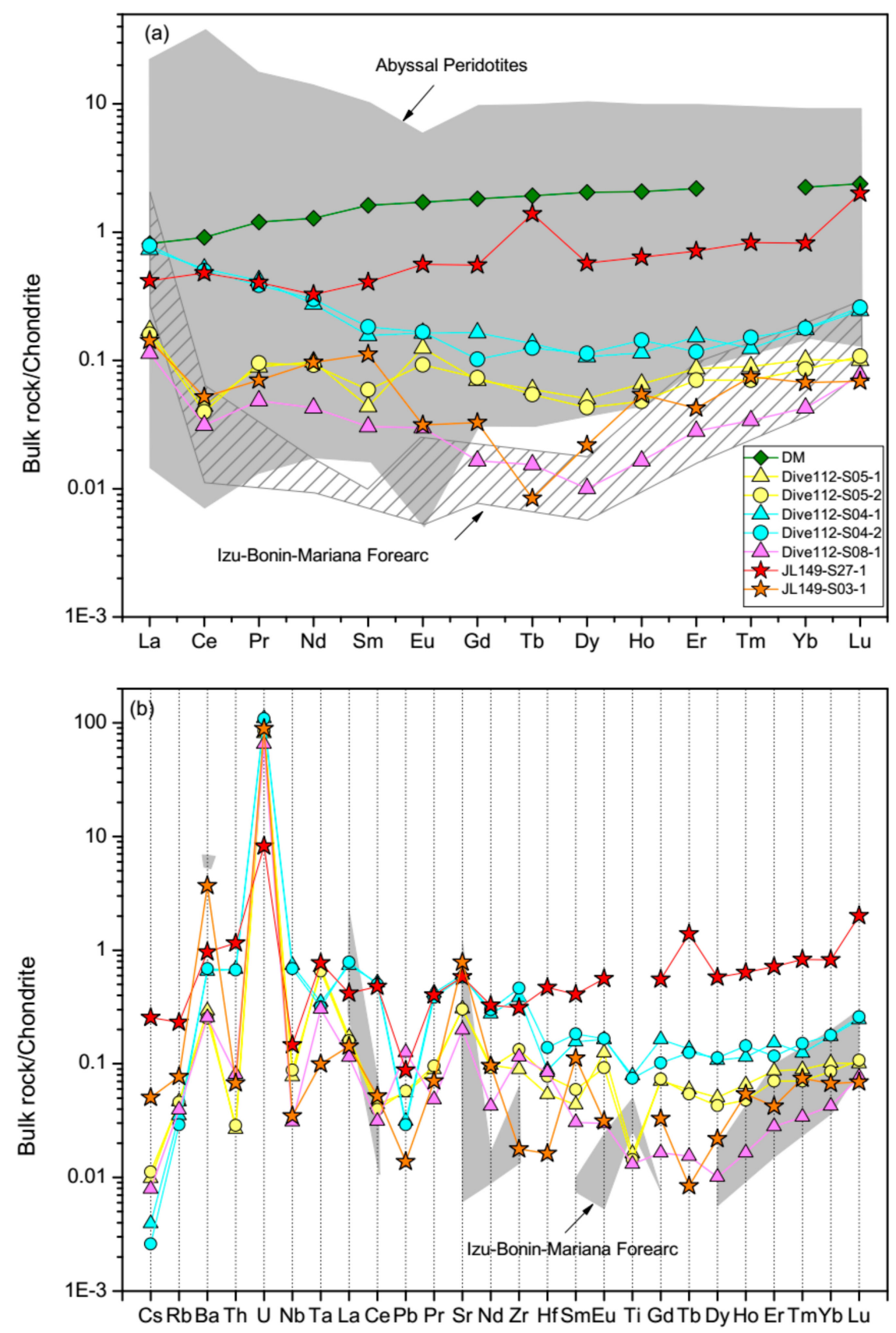

Figure 3. (a) Chondrite-normalized rare earth element patterns and (b) a trace element spider diagram of the Yap Trench peridotites. JL149 samples are from the southern Yap Trench. Chondrite values are from Anders and Grevesse (1989) [42]. Fields for the abyssal peridotites [38] and the Izu-Bonin-Mariana forearc peridotites [39] are shown for comparison. Data for the depleted mantle (DM) are from Workman and Hart (2005) [43].

\subsection{Re-Os Isotopes}

Compositions of Re-Os elements and Re-Os isotopes are listed in Table 2. The Re content in Yap Trench peridotites has a narrow range of $0.06-0.24 \mathrm{ppb}$, which is slightly higher than that of the peridotite xenoliths from subduction zones [17] but is lower than the value of most abyssal peridotites (Figure 4a). Nearly all peridotites from the Yap Trench have an Os content of less than $1.5 \mathrm{ppb}(0.30-1.26)$ and are plotted in the low Os end of the fields of both abyssal and subduction zone peridotites (Figure $4 \mathrm{~b}$ ); the exception is sample JL149-S03-1, which has a high Os content (4.18 ppb). The ${ }^{187} \mathrm{Os} /{ }^{188} \mathrm{Os}$ ratios of the Yap Trench peridotites vary over a wide range (0.12043-0.14867), with the highest value comparable to 
that of the dunite from mid-ocean ridge [44] and the lowest value comparable to the most unradiogenic Os isotope (0.11933) discovered in subduction zone peridotites [45] (Figure 4b). The most unradiogenic ${ }^{187} \mathrm{Os} /{ }^{188} \mathrm{Os}$ ratio occurs in sample JL149-S03-1, which has the lowest $\mathrm{Al}_{2} \mathrm{O}_{3}$ and $\mathrm{CaO}$ content and a relatively low rare earth element (REE) content among the Yap Trench peridotites. There are no obvious correlations between Os and ${ }^{187} \mathrm{Os} /{ }^{188} \mathrm{Os}$ of the oceanic peridotites; however, anomalously radiogenic values are limited to samples with Os content less than $2 \mathrm{ppb}$ (Figure $4 \mathrm{~b}$ ). In general, the oceanic peridotites show a positive correlation between $\mathrm{Al}_{2} \mathrm{O}_{3}$ and ${ }^{187} \mathrm{Os} /{ }^{188} \mathrm{Os}$, which represents a melt depletion trend. Some Yap Trench peridotites, however, show a trend that intersects with melt depletion trend, which is characterized by an increase in ${ }^{187} \mathrm{Os} /{ }^{188} \mathrm{O}$ s with a constant $\mathrm{Al}_{2} \mathrm{O}_{3}$ (Figure 5).

Table 2. Re-Os element concentration and Re-Os isotope compositions of the Yap Trench peridotites

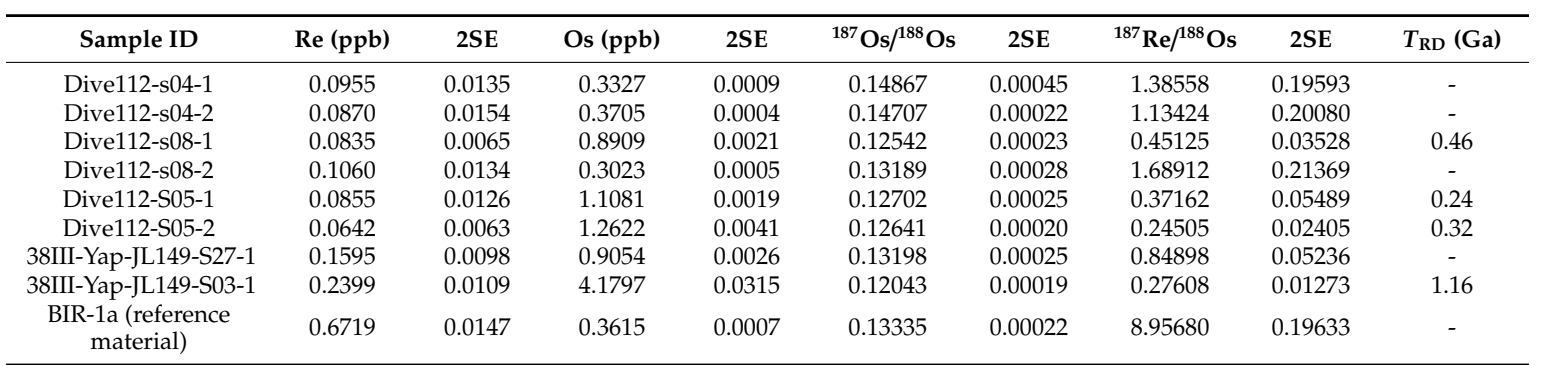

$T_{\mathrm{RD}}$ : Time of rhenium depletion age, calculated as: $1 / \lambda{ }^{*} \ln \left[\left({ }^{187} \mathrm{Os} /{ }^{188} \mathrm{Os}_{\text {chondrite }}-{ }^{187} \mathrm{Os} /{ }^{188} \mathrm{Os}_{\text {sample }}\right) /{ }^{187} \mathrm{Re} /{ }^{188} \mathrm{Os}_{\text {chondrite }}\right.$ +1 ] [2]. Calculating parameters are from Pearson et al. (2002) [46]. SE: Standard Error.

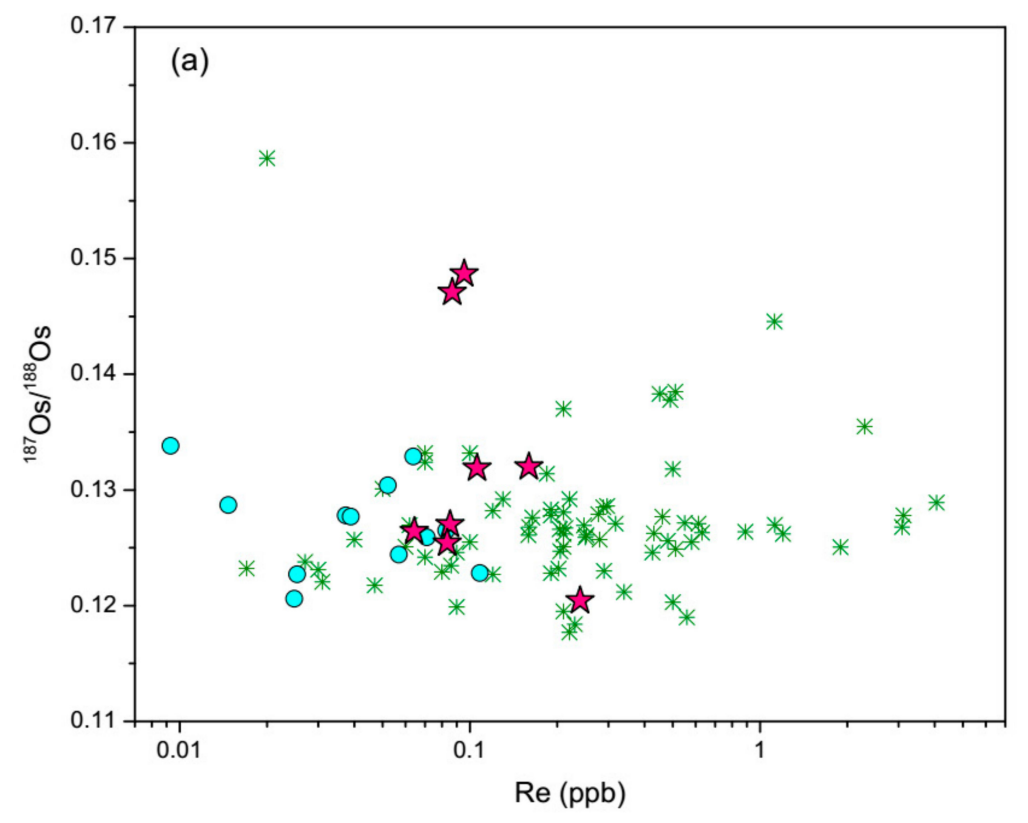

Figure 4. Cont. 


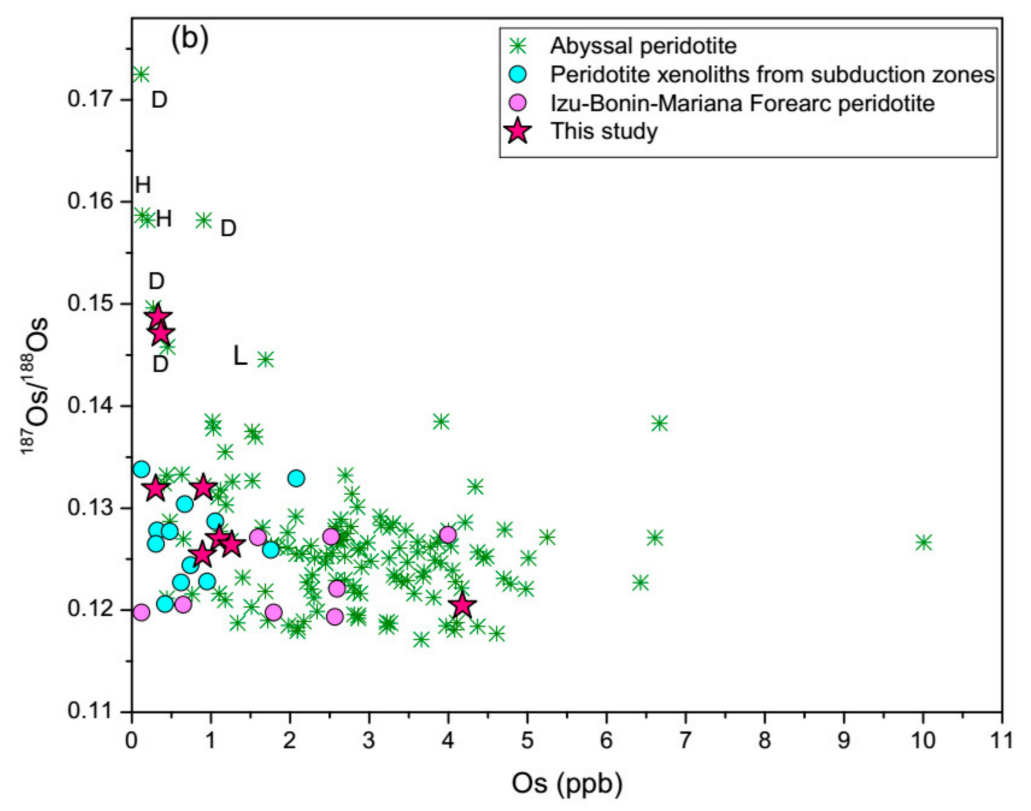

Figure 4. Plots of ${ }^{187} \mathrm{Os} /{ }^{188}$ Os versus the (a) Re and (b) Os content of the Yap Trench peridotites. D, H, and L represent dunite, harzburgite, and lherzolite, respectively. The abyssal peridotites [7,9-12,44], the peridotite xenoliths from subduction zones [17], and the Izu-Bonin-Mariana forearc peridotites [18] are shown for comparison.

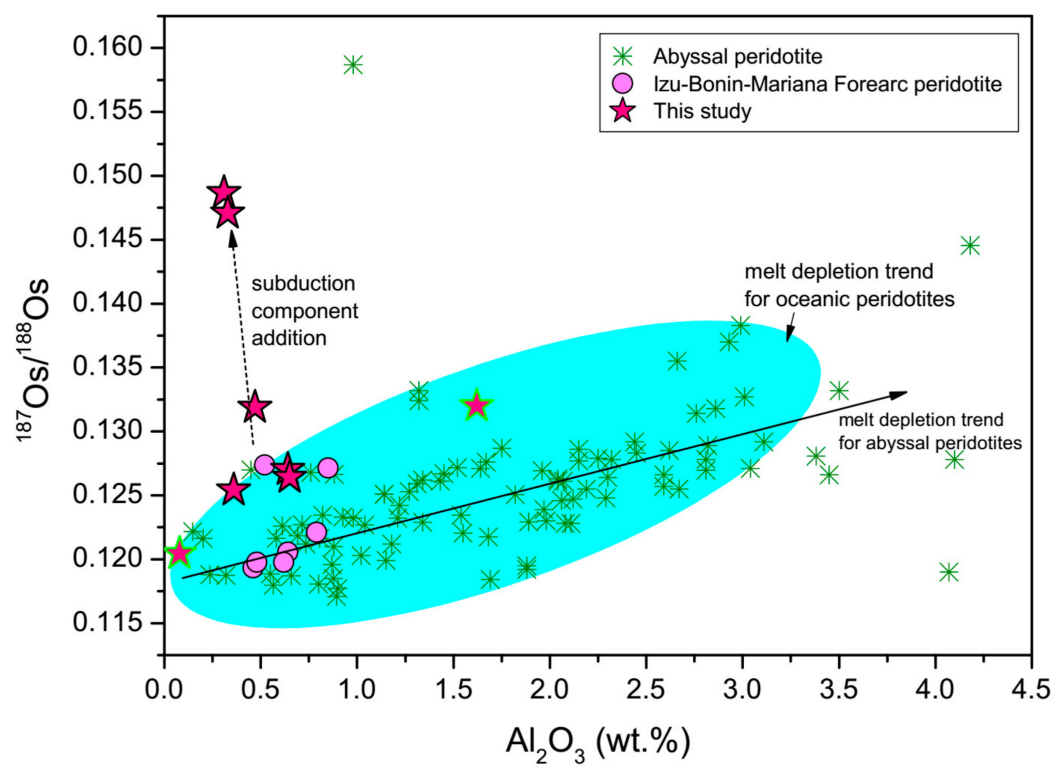

Figure 5. Plot of ${ }^{187} \mathrm{Os} /{ }^{188} \mathrm{Os}$ versus $\mathrm{Al}_{2} \mathrm{O}_{3}$ content of the Yap Trench peridotites. Data sources are the same as in Figure 4. Samples from the southern Yap Trench are shown by stars with green border. The cyan field shows the general trend of typical oceanic peridotites. Solid arrows show the melt depletion trends for abyssal peridotites. Dashed arrows show the subduction component addition trend for the Yap Trench peridotites.

\section{Discussion}

\subsection{Seawater and Fluid Alteration}

As residues of mantle melting, peridotites are commonly used to detect information on the oceanic upper mantle beneath a mid-ocean ridge and subduction zone $[27,38,39,47,48]$. Unfortunately, most oceanic peridotites have been modified by secondary alteration processes such as serpentinization 
and sea-floor contamination [49-51], which results in ambiguity when discussing the deep mantle processes. The Yap Trench peridotites have high LOI (12.38-14.06) and show elevated concentrations of fluid mobile elements—-such as $\mathrm{U}, \mathrm{Pb}$, and $\mathrm{Sr}$ - which represents characteristics resulting from serpentinization and seawater alteration of oceanic peridotites $[38,48,51]$ and is consistent with the presence of serpentine, observed petrographically [27]; however, these modifications are generally thought to be restricted in elements that are highly mobile in fluid [38]. Most major elements seems unaffected by alteration processes, which is supported by the general correlations between major elements (Figure 2) and by the observation that the peridotites do not deviate significantly from the "terrestrial array" [41] in the $\mathrm{Al}_{2} \mathrm{O}_{3} / \mathrm{SiO}_{2}-\mathrm{MgO} / \mathrm{SiO}_{2}$ diagram (Figure 2d). The slope of the trend defined by the Yap Trench peridotites is close to that of the terrestrial array, indicating that $\mathrm{Al}_{2} \mathrm{O}_{3}$ is not significantly modified by secondary processes.

Previous studies have suggested that the Re in peridotites is potentially elevated by alteration processes [7,9,52,53]; however, the Yap Trench peridotites have relatively lower Re values (0.06-0.24 ppb) compared to the value of the primitive mantle $(0.34 \mathrm{ppb})$ and the abyssal peridotites (Figure $4 \mathrm{a})$, implying that most of the Re was removed from the mantle and that there was no significant addition of Re to the peridotites after melting. As a compatible element, the Os content in the mantle will increase with the increase in the degree of mantle melting. The Yap Trench peridotites are characterized by high $\mathrm{MgO}$ and low $\mathrm{Al}_{2} \mathrm{O}_{3}, \mathrm{CaO}$, and HREE content, indicating a high mantle melting degree. Thus, the highly depleted Yap Trench peridotites should have high Os content, which is inconsistent with the observation that most of them have lower Os values than abyssal peridotites do (1-5 ppb) (Figure 4b). This contrast indicates that Os in peridotites should have been affected by processes other than mantle melting. It has been suggested that mantle Os may be partly lost during seawater alteration [7], leading to lower Os concentrations in abyssal peridotites compared to orogenic lherzolites [4,54]. During the alteration processes in oxidizing conditions, sulfides-which are a major Os carrier in peridotites [54] - are not as stable as they are in less oxidizing regimes and may therefore be oxidized to sulfates [55]. In addition, Os will behave as a moderately incompatible element during alteration, which could possibly promote its mobility [4]. Considering that the Yap Trench peridotites have experienced varying degrees of seafloor weathering and serpentinization, it can be inferred that the low Os content and high Re/Os ratio in the depleted Yap Trench peridotites were partly affected by seawater alteration, at least for the three samples with Os content lower than $0.5 \mathrm{ppb}$ and Re/Os content higher than 0.2 (Figures 4 and 6).

Researchers have long debated whether seawater alteration could increase the radiogenic Os isotopes of oceanic peridotites $[7,10,12,17,45,56]$. Even though seawater has over six orders of magnitude less Os than peridotite, it is possible to significantly modify the Os isotopic composition of peridotites via seawater alteration because the ${ }^{187} \mathrm{Os} /{ }^{188} \mathrm{Os}$ in seawater is much higher than that in mantle ( 1 compared to $\sim 0.127$ for the bulk Earth), which largely reduces the amount of added water needed to modify the Os isotopic composition in peridotites [7]. Modification of the ${ }^{187}$ Os/ $/{ }^{188}$ Os ratio by the hydrothermal alteration and seafloor weathering of peridotites has been reported in several studies $[7,17,44]$. Some oceanic peridotites contain cracks filled with $\mathrm{MnO}_{2}$ or are covered by $\mathrm{MnO}_{2}$ rinds, which generally contain high concentrations (up to $3 \mathrm{ppb}$ ) of radiogenic Os [57]); thus, they may significantly increase the ${ }^{187} \mathrm{Os} /{ }^{188}$ Os ratio of the peridotites $[4,7,44,58,59]$. There are several studies, however, suggest that the difference in ${ }^{187} \mathrm{Os} /{ }^{188} \mathrm{Os}$ ratio between weathered rims and fresh interiors of abyssal peridotites is small [10] and that the Os isotopic compositions in peridotites mainly record the information of high temperature mantle processes [12,18].

The Yap Trench peridotites have a wide range of ${ }^{187} \mathrm{Os} /{ }^{188} \mathrm{Os}$ ratios $(0.12043-0.14867)$ and the highly radiogenic ${ }^{187} \mathrm{Os} /{ }^{188} \mathrm{Os}$ ratios seem to be affected by seawater alteration. Because there is no correlation between ${ }^{187} \mathrm{Os} /{ }^{188} \mathrm{Os}$ and the $\mathrm{U}$ (fluid mobile element) of the Yap Trench peridotites (Figure 7), alteration may not be the only process that account for the increasing of the ${ }^{187} \mathrm{Os} /{ }^{188} \mathrm{Os}$ ratio. However, samples with the most radiogenic Os have the highest $U$ content and demonstrate significantly altered appearances in hand specimens (Dive 112-S04-1) (Figure 2b in Chen et al., 2019 [27]) 
and high LREE enrichment in REE patterns (Figure 3a), suggesting that the significant increase of radiogenic Os should be related to secondary alteration. Apart from alteration by seawater, peridotites from subduction zones also can be affected by slab-derived water-rich fluids; therefore, the recent addition of radiogenic Os from subducted oceanic crust and sediments may play a role in elevating the radiogenic Os content of the two highly altered samples [17,60,61]. This is supported by the subduction component addition trend in the ${ }^{187} \mathrm{Os} /{ }^{188} \mathrm{Os}$ vs. $\mathrm{Al}_{2} \mathrm{O}_{3}$ diagram (Figure 5), which is consistent with the addition of a component with high radiogenic Os and low $\mathrm{A}_{2} \mathrm{O}_{3}$ to the depleted mantle, as $\mathrm{Al}$ is sparingly soluble in the slab-derived water-rich fluids [62]. Modification of Os isotope compositions in the other six Yap Trench samples cannot be excluded because two of them have suprachondritic ${ }^{187} \mathrm{Os} /{ }^{188} \mathrm{Os}$ ratios; however, these samples show generally positive correlations in the ${ }^{187} \mathrm{Os} /{ }^{188} \mathrm{Os}$ vs. $\mathrm{Al}_{2} \mathrm{O}_{3}$ diagrams (Figure 5), indicating that alteration disturbance in Re-Os isotope systematics of these samples is not as strong as the two highly altered samples.

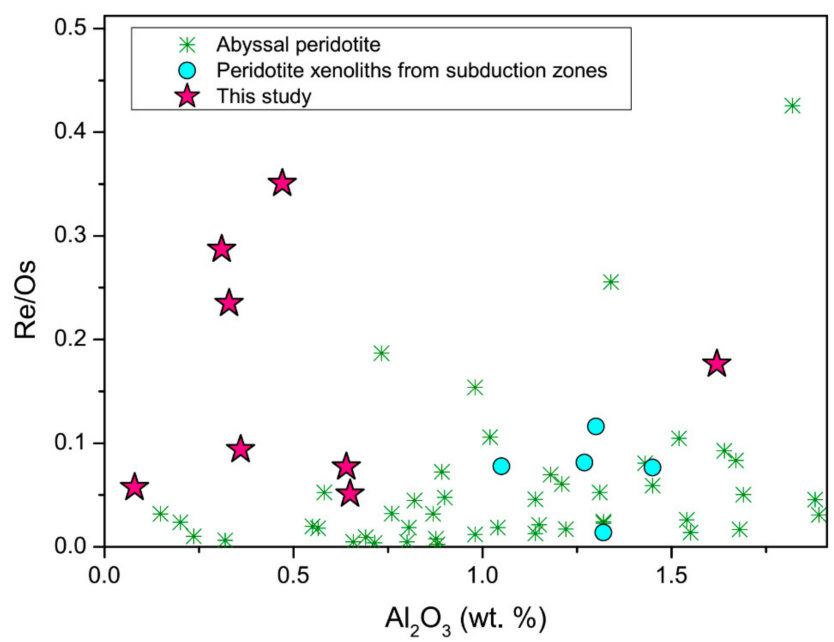

Figure 6. Plot of $\mathrm{Re} / \mathrm{Os}$ versus $\mathrm{Al}_{2} \mathrm{O}_{3}$ content of the Yap Trench peridotites. Data sources are the same as in Figure 4.

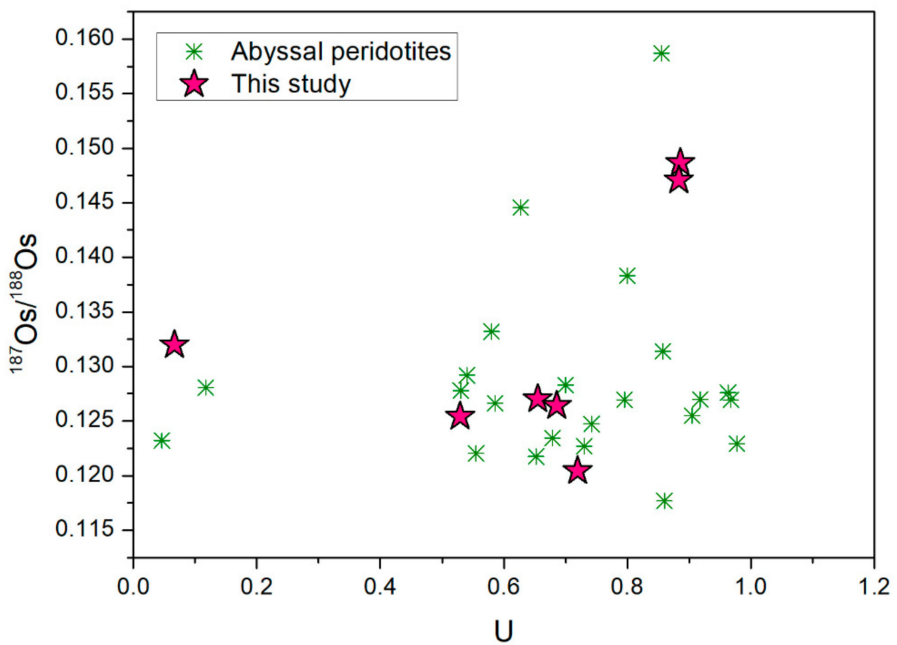

Figure 7. Plot of ${ }^{187} \mathrm{Os} /{ }^{188} \mathrm{Os}$ versus U content of the Yap Trench peridotites. Data sources are the same as in Figure 4.

\subsection{Melt Refertilization}

Melt refertilization is very common in oceanic peridotites, leading to the enrichment of LREEs and other highly incompatible elements observed in abyssal peridotites $[48,63]$ and peridotites from subduction zones [45]. The Yap Trench peridotites also show evidence of interaction between 
slab-derived melts and mantle wedges [27]. As the half-life of the ${ }^{187} \operatorname{Re}$ decays to ${ }^{187} \mathrm{Os}$ is about 42 billion years [1], there is significant divergence in ${ }^{187} \mathrm{Os} /{ }^{188} \mathrm{Os}$ ratios between basalts $(0.125-0.23)$ and depleted mantle residue (0.12-0.13) [6]. However, Os concentration in basalts are two orders of magnitude lower than that of the mantle peridotites; thus, the Os isotopes of mantle peridotites are thought to be insensitive to late processes related to basaltic melts. Whereas in subduction zones, evidence for recycling of radiogenic Os from the subducted slabs to the mantle wedge have been widely reported [8,16]. The high halogen (i.e., $\mathrm{Cl}$ and $\mathrm{F}$ ) contents and oxygen fugacities of the slab-released fluids or melts may convert Os into a mobile element in subduction zone environments $[16,64]$. Even though it is difficult to distinguish the contribution of fluids and melts in controlling Os isotopes, the highly radiogenic ${ }^{187} \mathrm{Os} /{ }^{188} \mathrm{Os}$ ratios in peridotites that sample the mantle wedge did confirm the disturbance of Os isotopes by slab-derived components $[17,60,61,65,66]$.

The positive correlation between ${ }^{187} \mathrm{Os} /{ }^{188} \mathrm{Os}$ ratios and high field-strength elements $(\mathrm{Nb}$ and $\mathrm{Zr}$ ) suggests that melt refertilization should play a role in increasing the radioactive Os isotopic composition of the Yap Trench peridotites (Figure 8). Melt refertilization has a negligible effect on the Os isotopic compositions of peridotites except when there is a high melt/rock ratio and low Os content in peridotites $[12,16]$. Some dunites from the Southwest Indian Ridge have highly radiogenic ${ }^{187} \mathrm{Os} /{ }^{188} \mathrm{Os}$, which may be related to the high melt/rock ratio of the melt channels [44]. Additionally, low Os contents and radiogenic ${ }^{187} \mathrm{Os} /{ }^{188}$ Os were also observed in ophiolite peridotites affected by penetrating melts under high melt/rock ratios [67]. As shown in Figure $4 b$, mantle peridotites can be divided into two groups; one group are characterized by low Os concentrations $(<2 \mathrm{ppb})$ and variable Os isotopic compositions due to the occurrence of highly radiogenic ${ }^{187} \mathrm{Os} /{ }^{188} \mathrm{Os}$ ratios; another group are characterized by higher Os concentrations $\left(>2 \mathrm{ppb}\right.$ ) and unradiogenic ${ }^{187} \mathrm{Os} /{ }^{188} \mathrm{Os}$ ratios. Peridotites with extremely high ${ }^{187} \mathrm{Os} /{ }^{188} \mathrm{Os}$ ratios $(>0.145)[12,44]$ generally have Os contents lower than $0.5 \mathrm{ppb}$ (Figure $4 \mathrm{~b}$ ) implying that the primary unradiogenic Os should have been removed from the peridotites if melt refertilization did affect the Os isotope composition. Therefore, the Yap Trench peridotites should have been affected by penetrating melts under high melt/rock ratios, this is reasonable because tectonic erosion was enhanced by subducting of the Caroline ridge, thus more slab-derived melts were transported into the mantle wedge. During this process, the primary sulfides with unradiogenic Os were dissolved by the penetrating melts and secondary sulfides with radiogenic Os were segregated from the melts into mantle peridotites.

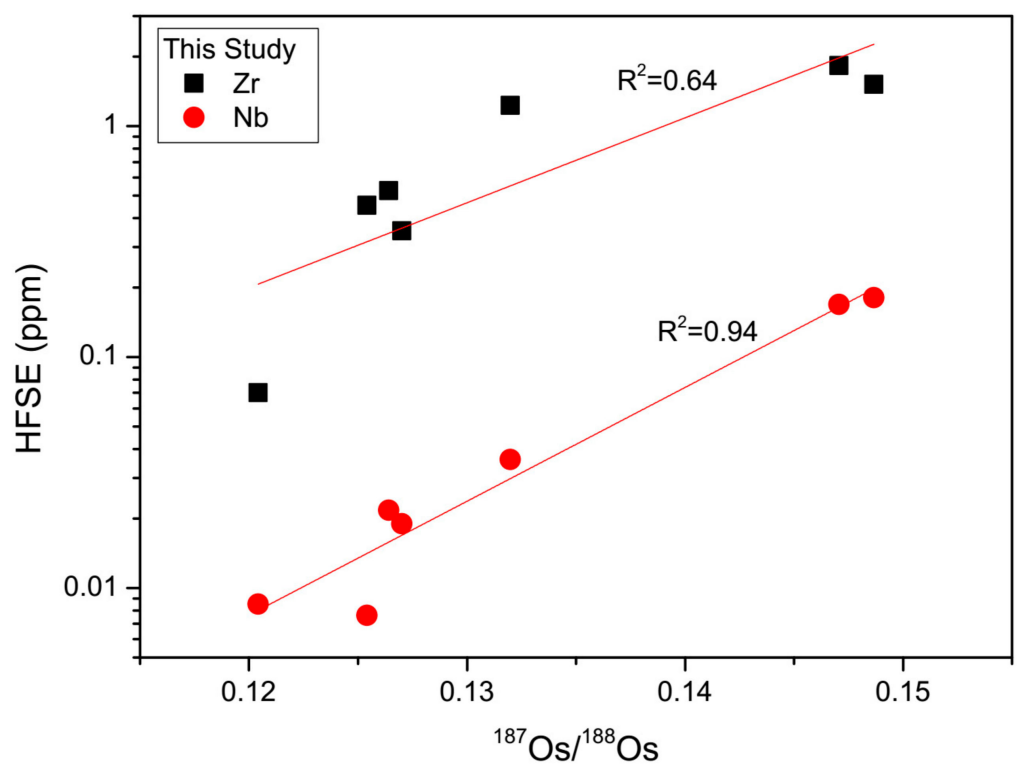

Figure 8. Plot of ${ }^{187} \mathrm{Os} /{ }^{188} \mathrm{Os}$ versus high field-strength elements (HFSE) ( $\mathrm{Zr}$ and $\mathrm{Nb}$ ) content of the Yap Trench peridotites. Correlation lines are drawn by linear fit. 


\subsection{Ancient Melting Event}

Studies of major and trace elements of peridotites have inferred that there may be old mantle fragments present in the oceanic asthenosphere $[48,68]$, which has been confirmed by unradiogenic ${ }^{187} \mathrm{Os} /{ }^{188} \mathrm{Os}$ ratios recorded in abyssal peridotite [8-11,69], ophiolite peridotite [70,71], and forearc mantle peridotite [18]. This suggests that ancient melting events are ubiquitously recorded in the oceanic mantle. Nevertheless, when Os isotopes are considered, it should be ensured that they have not been significantly disturbed by secondary processes such as fluid alteration and melt refertilization. The correlation between $\mathrm{Al}_{2} \mathrm{O}_{3}$ content and the ${ }^{187} \mathrm{Os} /{ }^{188} \mathrm{Os}$ ratio is a useful proxy to evaluate whether the peridotites preserve magmatic information. Here, $\mathrm{Al}_{2} \mathrm{O}_{3}$ instead of $\mathrm{Re} / \mathrm{Os}$ is used because rhenium is more likely to be affected by late processes than aluminum is. The positive correlation between $\mathrm{Al}_{2} \mathrm{O}_{3}$ and the ${ }^{187} \mathrm{Os} /{ }^{188} \mathrm{Os}$ ratio in peridotites was widely observed in orogenic peridotites [52], abyssal peridotites [10], and forearc mantle peridotites [18], and was thought to indicate that the peridotites are inherited from one or more melting events [11].

Previous sections have shown that the Os isotope in the Yap Trench peridotites have been modified by fluid alteration and melt refertilization, especially for three samples with high ${ }^{187} \mathrm{Os} /{ }^{188} \mathrm{Os}$ ratios that obviously deviate from the general trend of the oceanic peridotites (Figure 5). The other five samples show positive correlation between $\mathrm{Al}_{2} \mathrm{O}_{3}$ and ${ }^{187} \mathrm{Os} /{ }^{188} \mathrm{Os}$ ratio, implying that to some extent these samples preserve the signature of the melting events. However, compositional trend of these samples has a higher slope than that of the trend defined by the abyssal peridotites (Figure 5), which means that, for a given $\mathrm{Al}_{2} \mathrm{O}_{3}$, the subduction-related peridotites are shifted on average to a higher ${ }^{187} \mathrm{Os} /{ }^{188} \mathrm{Os}$ ratio. These features are consistent with the modification of the peridotites by late processes. Considering that the radiogenic Os will be increased by late processes, low ${ }^{187} \mathrm{Os} /{ }^{188} \mathrm{Os}$ ratios in the peridotite are more likely to record the true melting history. It is documented that the ${ }^{187} \mathrm{Os} /{ }^{188} \mathrm{Os}$ composition of the convecting upper mantle is related to both the melting degree and the melting age of the mantle [11]. Low ${ }^{187} \mathrm{Os} /{ }^{188} \mathrm{Os}$ ratios (sub-chondritic) in peridotites are indicative of a long-term evolution in a low Re-Os environment. Thus, the most unradiogenic Os isotopic composition of sample JL149-S03-1 may indicate that the peridotite is inherited from ancient melting events. The age of the melting event can be estimated by calculating the Re-depletion age $\left(T_{\mathrm{RD}}\right)$, which assumes that all Re is extracted from the mantle during partial melting [72]. The $T_{\mathrm{RD}}$ age represents the minimum ages of melt extraction because, in most cases, it is unlikely for all the Re to be removed from the mantle after melting. Thus, the $\mathrm{T}_{\mathrm{RD}}$ ages are closer to the true melting age in highly depleted peridotites than in less depleted peridotites. The $\mathrm{T}_{\mathrm{RD}}$ values (relative to chondrite) for the studied Yap Trench peridotites were calculated following the equation and parameters from Shirey and Walker (1998) [2] and Pearson et al. (2002) [46]. The results show that the melt extraction age is $0.24-1.16$ Ga for the four unradiogenic (sub-chondritic) samples (Table 2). The wide range of the depletion age requires mantles with different evolution histories to be juxtaposed within the forearc mantle section. The maximum age $(1.16 \mathrm{Ga})$ of the Yap Trench sample is comparable to the oldest age $(0.82-1.23 \mathrm{Ga})$ that has been recorded in the IBM forearc mantle peridotites [18]. The beginning of the Yap subduction system was contemporaneous with and part of the formation of the IBM arc-trench system around 51-40 Ma [20,73,74], which means that, similar to the IBM forearc mantle [18], there may be episodic melting events in the Yap forearc mantle. This is supported by the observation that the oldest age occurs in the most depleted sample (JL149-S03-1), because a single melting event such as melting during the initiation of subduction [27] cannot account for the highly depleted peridotites with unradiogenic Os isotopes. It is documented that the asthenospheric mantle beneath the Philippine Sea Plate (PSP) has invaded into the forearc area of the southern Mariana Trench due to the shrinking of the PSP [32]. This large-scale asthenospheric flow may also have an impact on the Yap Trench, which is located to the south of the Mariana Trench, where slab gaps were inferred to induce mantle outflow from the shrinking PSP [32]. Thus, the Yap Trench peridotites may represent a residual mantle that experienced episodic melting events, including Proterozoic ancient mantle melting, back-arc mantle melting beneath the PSP, and mantle melting induced by forearc spreading at the earliest stage of subduction initiation [27]. 


\subsection{Os Isotopic Heterogeneity in the Oceanic Asthenosphere}

The wide range of the ${ }^{187} \mathrm{Os} /{ }^{188} \mathrm{Os}$ ratio in the Yap Trench peridotites indicates that the mantle wedge is heterogeneous in its Os isotopic composition. Peridotites from the southern Yap Trench plot in both the most depleted and fertile ends of the array of the studied samples (Figure 5), which reflects the coexistence of fertile mantle domains with relatively radiogenic ${ }^{187} \mathrm{Os} /{ }^{188} \mathrm{Os}$ ratios and refractory domains with unradiogenic ${ }^{187} \mathrm{Os} /{ }^{188} \mathrm{Os}$ ratios. The heterogeneity of the Os isotopic composition is inherited from both asthenospheric heterogeneity and lithospheric heterogeneity, which are mainly reflected by unradiogenic (sub-chondritic) and radiogenic (super-chondritic) Os isotopic composition, respectively. Lithospheric heterogeneity is more common and easier to identify than asthenospheric heterogeneity because the addition of radiogenic Os can be achieved by most late processes, and, meanwhile, the primary asthenospheric signals (unradiogenic Os) were blurred; therefore, the unradiogenic Os in the oceanic asthenosphere is underestimated based on the observations of oceanic peridotites, and the age of melt depletion reflected by ${ }^{187} \mathrm{Os} /{ }^{188} \mathrm{Os}$ ratios should be older than estimated.

As modification by late processes, including melt refertilization and fluid alteration, are common features in oceanic peridotites, the identification of asthenospheric heterogeneity is very important to establish the evolution history of the convecting upper mantle. A variety of studies have suggested that the asthenospheric mantle is heterogeneous in Os isotopes and that these heterogeneities can survive on long timescales (several billion years) in the convecting upper mantle [8-12,18]. A depleted mantle with unradiogenic Os making a great contribution to the heterogeneity of the asthenosphere indicates that the old mantle fragment is widespread in the asthenospheric mantle and was not homogenized by the convective stirring. This may be related to the contrast in density between the highly depleted and fertile mantle. The refractory old mantle fragment has a lower density $[75,76]$ than the fertile mantle does and will therefore float above the "normal" asthenosphere, leading to high stability resisting mantle convection. The late processes may mask the primary mantle information and make it difficult to identify the ancient melting residue; thus, the amount of old mantle fragment is underestimated in the oceanic convecting mantle. Similar old mantle peridotites are also presented beneath the IBM forearc [18]. Therefore, the old depleted mantle domain, as a material that contrasts with isotopically enriched components such as recycled oceanic crust, may make a significant contribution to the chemical heterogeneity of the oceanic mantle.

\section{Conclusions}

The highly depleted Yap Trench peridotites are rich in LREEs and highly incompatible elements, implying that they were affected by late processes such as fluid alteration and melt refertilization. During these late processes, Os may become mobile and be removed from the mantle, leading to extremely low Os content in the depleted Yap Trench peridotites. Fluid alteration and melt refertilization also have increased the ${ }^{187} \mathrm{Os} /{ }^{188} \mathrm{Os}$ ratios of the mantle, resulting in a wide range of ${ }^{187} \mathrm{Os} /{ }^{188} \mathrm{Os}$ ratios (0.12043-0.14867, from sub-chondritic to suprachondritic) for the Yap Trench peridotites. As the ${ }^{187} \mathrm{Os} /{ }^{188}$ Os ratio will be increased during late processes, the lowest ${ }^{187} \mathrm{Os} /{ }^{188} \mathrm{Os}$ ratio in the Yap Trench peridotites corresponds to a youngest Re-depletion age of $1.16 \mathrm{Ga}$ (relative to chondrite), which undoubtedly indicates an ancient melting event. This Proterozoic ancient melting, combined with probable back-arc mantle melting beneath the Philippine Sea Plate and forearc mantle melting during the earliest stage of subduction initiation, indicates that the Yap Trench mantle has a complex evolutionary history.

The discovery of mantle with a low ${ }^{187} \mathrm{Os} /{ }^{188} \mathrm{Os}$ ratio in the subduction zone suggests that the amount and distribution area of old mantle fragment is underestimated in the oceanic mantle, which is probably due to the addition of radiogenic Os isotopes to the mantle during late processes. The refractory old mantle fragment has a lower density than the normal mantle does and will therefore float above the asthenosphere. Such fragments can be preserved in the convecting upper mantle for several billion years, which can make a great contribution to the heterogeneity of the oceanic asthenospheric mantle. 
Author Contributions: L.C. and L.T. conceived and designed the concept of this study; L.C. and J.Z. wrote the original manuscript; X.L., W.W., Z.L., H.W., X.W. and F.C. have substantially revised the original manuscript.

Funding: This research was jointly funded by the Scientific Research Fund of the Second Institute of Oceanography, MNR (grant No. QNYC1901); the National Basic Research Program (973 Program) of China (grant No. 2015CB755905); the National Natural Science Foundation of China (grant No. 41706041; 41976072; 41706044; 91628301); the Natural Science Foundation of Zhejiang province, China (grant no. LQY18D060002); and the "13th Five-Year Plan" for Resources and Environment Projects of the China Ocean Mineral R\&D Association (COMRA) (grant No. DY135-G2-1-01; DY135-N1-1-01).

Acknowledgments: We are grateful to two anonymous reviewers for their constructive comments.

Conflicts of Interest: The authors declare no conflict of interest.

\section{References}

1. Shen, J.J.; Papanastassiou, D.A.; Wasserburg, G.J. Precise Re-Os determinations and systematics of iron meteorites. Geochim. Cosmochim. Acta 1996, 60, 2887-2900. [CrossRef]

2. Shirey, S.B.; Walker, R.J. The Re-Os isotope system in cosmochemistry and high-temperature geochemistry. Annu. Rev. Earth Planet. Sci. 1998, 26, 423-500. [CrossRef]

3. Burton, K.W.; Schiano, P.; Birck, J.L.; Allegre, C.J.; Rehkämper, M.; Halliday, A.N.; Dawson, J.B. The distribution and behaviour of rhenium and osmium amongst mantle minerals and the age of the lithospheric mantle beneath Tanzania. Earth Planet. Sci. Lett. 2000, 183, 93-106. [CrossRef]

4. Roy-Barman, M.; Allègre, C.J. 187Os/186Os ratios of mid-ocean ridge basalts and abyssal peridotites. Geochim. Cosmochim. Acta 1994, 58, 5043-5054. [CrossRef]

5. Schiano, P.; Birck, J.L.; Allègre, C.J. Osmium-strontium-neodymium-lead isotopic covariations in mid-ocean ridge basalt glasses and the heterogeneity of the upper mantle. Earth Planet. Sci. Lett. 1997, 150, 363-379. [CrossRef]

6. Escrig, S.; Schiano, P.; Schilling, J.G.; Allegre, C. Rhenium-osmium isotope systematics in MORB from the Southern Mid-Atlantic Ridge (40-50 S). Earth Planet. Sci. Lett. 2005, 235, 528-548. [CrossRef]

7. Snow, J.E.; Reisberg, L. Os isotopic systematics of the MORB mantle: Results from altered abyssal peridotites. Earth Planet. Sci. Lett. 1995, 133, 411-421. [CrossRef]

8. Brandon, A.D.; Snow, J.E.; Walker, R.J.; Morgan, J.W.; Mock, T.D. ${ }^{190}$ Pt- ${ }^{186}$ Os and ${ }^{187}$ Re- $-{ }^{187}$ Os systematics of abyssal peridotites. Earth Planet. Sci. Lett. 2000, 177, 319-335. [CrossRef]

9. Harvey, J.; Gannoun, A.; Burton, K.W.; Rogers, N.W.; Alard, O.; Parkinson, I.J. Ancient melt extraction from the oceanic upper mantle revealed by Re-Os isotopes in abyssal peridotites from the Mid-Atlantic ridge. Earth Planet. Sci. Lett. 2006, 244, 606-621. [CrossRef]

10. Liu, C.Z.; Snow, J.E.; Hellebrand, E.; Brügmann, G.; Von Der Handt, A.; Büchl, A.; Hofmann, A.W. Ancient, highly heterogeneous mantle beneath Gakkel ridge, Arctic Ocean. Nature 2008, 452, 311-316. [CrossRef]

11. Lassiter, J.C.; Byerly, B.L.; Snow, J.E.; Hellebrand, E. Constraints from Os-isotope variations on the origin of Lena Trough abyssal peridotites and implications for the composition and evolution of the depleted upper mantle. Earth Planet. Sci. Lett. 2014, 403, 178-187. [CrossRef]

12. Day, J.M.; Walker, R.J.; Warren, J.M. 186Os-187Os and highly siderophile element abundance systematics of the mantle revealed by abyssal peridotites and Os-rich alloys. Geochim. Cosmochim. Acta. 2017, 200, 232-254. [CrossRef]

13. Bizimis, M.; Griselin, M.; Lassiter, J.C.; Salters, V.J.; Sen, G. Ancient recycled mantle lithosphere in the Hawaiian plume: Osmium-hafnium isotopic evidence from peridotite mantle xenoliths. Earth Planet. Sci. Lett. 2007, 257, 259-273. [CrossRef]

14. Meibom, A.; Frei, R. Evidence for an ancient osmium isotopic reservoir in Earth. Science 2002, 296, 516-518. [CrossRef] [PubMed]

15. Frei, R.; Gervilla, F.; Meibom, A.; Proenza, J.A.; Garrido, C.J. Os isotope heterogeneity of the upper mantle: Evidence from the Mayari-Baracoa ophiolite belt in eastern Cuba. Earth Planet. Sci. Lett. 2006, 241, 466-476. [CrossRef]

16. Liu, C.Z.; Wu, F.Y.; Chu, Z.Y.; Ji, W.Q.; Yu, L.J.; Li, J.L. Preservation of ancient Os isotope signatures in the Yungbwa ophiolite (southwestern Tibet) after subduction modification. J. Asian Earth Sci. 2012, 53, 38-50. [CrossRef] 
17. Brandon, A.D.; Creaser, R.A.; Shirey, S.B.; Carlson, R.W. Osmium recycling in subduction zones. Science 1996, 272, 861-863. [CrossRef]

18. Parkinson, I.J.; Hawkesworth, C.J.; Cohen, A.S. Ancient mantle in a modern arc: Osmium isotopes in Izu-Bonin-Mariana forearc peridotites. Science 1998, 281, 2011-2013. [CrossRef]

19. Seno, T.; Stein, S.; Gripp, A.E. A model for the motion of the Philippine Sea plate consistent with NUVEL-1 and geological data. J. Geophys. Res. Solid Earth 1993, 98, 17941-17948. [CrossRef]

20. Fujiwara, T.; Tamura, C.; Nishizawa, A.; Fujioka, K.; Kobayashi, K.; Iwabuchi, Y. Morphology and tectonics of the Yap Trench. Mar. Geophys. Res. 2000, 21, 69-86. [CrossRef]

21. Crawford, A.J.; Beccaluva, L.; Serri, G.; Dostal, J. Petrology, geochemistry and tectonic implications of volcanics dredged from the intersection of the Yap and Mariana trenches. Earth Planet. Sci. Lett. 1986, 80, 265-280. [CrossRef]

22. Nagihara, S.; Kinoshita, M.; Fujimoto, H.; Katao, H.; Kinoshita, H.; Tomoda, Y. Geophysical observations around the northern Yap trench: Seismicity, gravity and heat flow. Tectonophysics 1989, 163, 93-104. [CrossRef]

23. Sato, T.; Kasahara, J.; Katao, H.; Tomiyama, N.; Mochizuki, K.; Koresawa, S. Seismic observations at the Yap Islands and the northern Yap Trench. Tectonophysics 1997, 271, 285-294. [CrossRef]

24. Ohara, Y.; Fujioka, K.; Ishizuka, O.; Ishii, T. Peridotites and volcanics from the Yap arc system: Implications for tectonics of the southern Philippine Sea Plate. Chem. Geol. 2002, 189, 35-53. [CrossRef]

25. Lee, S.M. Deformation from the convergence of oceanic lithosphere into Yap trench and its implications for early-stage subduction. J. Geodyn. 2004, 37, 83-102. [CrossRef]

26. Yang, Y.; Wu, S.; Gao, J.; Tian, L.; Yang, J.; Xu, Y. Geology of the Yap Trench: New observations from a transect near $10^{\circ} \mathrm{N}$ from manned submersible Jiaolong. Int. Geol. Rev. 2018, 60, 1941-1953. [CrossRef]

27. Chen, L.; Tang, L.; Li, X.; Dong, Y.; Yu, X.; Ding, W. Geochemistry of peridotites from the Yap Trench, Western Pacific: Implications for subduction zone mantle evolution. Int. Geol. Rev. 2019, 61, 1037-1051. [CrossRef]

28. Shiraki, K. Metamorphic basement rocks of Yap Islands, western Pacific: Possible oceanic crust beneath an island arc. Earth Planet. Sci. Lett. 1971, 13, 167-174. [CrossRef]

29. Hawkins, J.; Batiza, R. Metamorphic rocks of the Yap arc-trench system. Earth Planet. Sci. Lett. 1977, 37, 216-229. [CrossRef]

30. Hilde, T.W. Sediment subduction versus accretion around the Pacific. Tectonophysics 1983, 99, $381-397$. [CrossRef]

31. Dong, D.; Zhang, Z.; Bai, Y.; Fan, J.; Zhang, G. Topographic and sedimentary features in the Yap subduction zone and their implications for the Caroline Ridge subduction. Tectonophysics 2018, 722, 410-421. [CrossRef]

32. Ribeiro, J.M.; Stern, R.J.; Martinez, F.; Woodhead, J.; Chen, M.; Ohara, Y. Asthenospheric outflow from the shrinking Philippine Sea Plate: Evidence from Hf-Nd isotopes of southern Mariana lavas. Earth Planet. Sci. Lett. 2017, 478, 258-271. [CrossRef]

33. Zanetti, A.; D'Antonio, M.; Spadea, P.; Raffone, N.; Vannucci, R.; Brugeir, O. Petrogenesis of mantle peridotites from the Izu-Bonin-Mariana (IBM) forearc. Ofioliti 2006, 31, 189-206.

34. Li, J.; Zhao, P.P.; Liu, J.G.; Wang, X.C.; Yang, Y.; Wang, G.Q.; Xu, J.F. Reassessment of Hydrofluoric Acid Desilicification in the Carius Tube Digestion Technique for Re-Os Isotopic Determination in Geological Samples. Geostand. Geoanal. Res. 2015, 39, 17-30. [CrossRef]

35. Li, J.; Liang, X.R.; Xu, J.F.; Suzuki, K.; Dong, Y.H. Simplified technique for the measurements of Re-Os isotope by multicollector inductively coupled plasma mass spectrometry (MC-ICP-MS). Geochem. J. 2010, 44, 73-80. [CrossRef]

36. Li, J.; Jiang, X.Y.; Xu, J.F.; Zhong, L.F.; Wang, X.C.; Wang, G.Q.; Zhao, P.P. Determination of platinum-group elements and Re-Os Isotopes using ID-ICP-MS and N-TIMS from a single digestion after two-stage column separation. Geostand. Geoanal. Res. 2014, 38, 37-50. [CrossRef]

37. Li, J.; Wang, X.C.; Xu, J.F.; Xu, Y.G.; Tang, G.J.; Wang, Q. Disequilibrium-induced initial Os isotopic heterogeneity in gram aliquots of single basaltic rock powders: Implications for dating and source tracing. Chem. Geol. 2015, 406, 10-17. [CrossRef]

38. Niu, Y. Bulk-rock major and trace element compositions of abyssal peridotites: Implications for mantle melting, melt extraction and post-melting processes beneath mid-ocean ridges. J. Petrol. 2004, 45, 2423-2458. [CrossRef] 
39. Parkinson, I.; Pearce, J.A.; Thirlwall, M.E.A.; Johnson, K.T.M.; Ingram, G. Trace element geochemistry of peridotites from the Izu-Bonin-Mariana forearc, Leg 125. Proc. Ocean Drill. Program Sci. Results 1992, 125, 487-506.

40. Saboda, K.L.; Fryer, P.; Maekawa, H. Metamorphism of ultramafic clasts from Conical Seamount: Sites 778, 779, and 780. Proc. Ocean Drill. Program Sci. Results 1992, 125, 431-443.

41. Jagoutz, E.; Palme, H.; Baddenhausen, H.; Blum, K.; Cendales, M.; Dreibus, G.; Spettel, B.; Lorentz, V.; Wänke, $\mathrm{H}$. The abundance of major, minor and trace elements in the Earth's mantle as derived from primitive ultramafic nodules. In Proceedings of the Lunar and Planetary Science Conference, Houston, TX, USA, 19-23 March 1979; Volume 2, pp. 2031-2050.

42. Anders, E.; Grevesse, N. Abundances of the elements: Meteoritic and solar. Geochim. Cosmochim. Acta 1989, 53, 197-214. [CrossRef]

43. Workman, R.K.; Hart, S.R. Major and trace element composition of the depleted MORB mantle (DMM). Earth Planet. Sci. Lett. 2005, 231, 53-72. [CrossRef]

44. Standish, J.J.; Hart, S.R.; Blusztajn, J.; Dick, H.J.B.; Lee, K.L. Abyssal peridotite osmium isotopic compositions from cr-spinel. Geochem. Geophys. Geosyst. 2002, 3, 1-24. [CrossRef]

45. Parkinson, I.J.; Pearce, J.A. Peridotites from the Izu-Bonin-Mariana forearc (ODP Leg 125): Evidence for mantle melting and melt-mantle interaction in a supra-subduction zone setting. J. Petrol. 1998, 39, 1577-1618. [CrossRef]

46. Pearson, D.G.; Irvine, G.J.; Carlson, R.W.; Kopylova, M.G.; Ionov, D.A. The Development of Lithospheric Keels Beneath the Earliest Continents: Time Constraints Using PGE and Re-Os Isotope Systematics; Special Publications; Geological Society: London, UK, 2002; Volume 199, pp. 65-90.

47. Johnson, K.T.M.; Dick, H.J.B.; Shimizu, N. Melting in the oceanic upper mantle: An ion microprobe study of diopsides in abyssal peridotites. J. Geophys. Res. 1990, 95, 2661-2678. [CrossRef]

48. Chen, L.; Chu, F.Y.; Zhu, J.H.; Dong, Y.H.; Yu, X.; Li, Z.G.; Tang, L.M. Major and trace elements of abyssal peridotites: Evidence for melt refertilization beneath the ultraslow-spreading Southwest Indian Ridge (53 E segment). Int. Geol. Rev. 2005, 57, 1715-1734. [CrossRef]

49. Snow, J.E.; Dick, H.J.B. Pervasive magnesium loss by marine weathering of peridotite. Geochim. Cosmochim. Acta 1995, 59, 4219-4235. [CrossRef]

50. Mével, C. Serpentinization of abyssal peridotites at mid-ocean ridges. Comptes Rendus Geosci. 2003, 335, 825-852. [CrossRef]

51. Paulick, H.; Bach, W.; Godard, M.; DeHoog, J.C.M.; Suhr, G.; Harvey, J. Geochemistry of abyssal peridotites (Mid-Atlantic Ridge, $15^{\circ} 20^{\prime}$ N, ODP Leg 209): Implications for fluid/rock interaction in slow spreading environments. Chem. Geol. 2006, 234, 179-210. [CrossRef]

52. Reisberg, L.; Lorand, J.P. Longevity of sub-continental mantle lithosphere from osmium isotope systematics in orogenic peridotite massifs. Nature 1995, 376, 159-162. [CrossRef]

53. Luguet, A.; Lorand, J.P.; Seyler, M. Sulfide petrology and highly siderophile element geochemistry of abyssal peridotites: A coupled study of samples from the Kane Fracture Zone (45 W 23 20N, MARK area, Atlantic Ocean). Geochim. Cosmochim. Acta 2003, 67, 1553-1570. [CrossRef]

54. Mitchell, H.; Keays, R. Abundance and distribution of gold, palladium and iridium in some spine1 and garnet Iherzolites: Implications for the nature and origin of precious metalrich intergranular components in the upper mantle. Geochim. Cosmochim. Acta 1981, 45, 2425-2442. [CrossRef]

55. Sakai, H.; Ueda, A.; Field, C.W. $\delta^{34}$ S and concentration of sulfide and sulfate sulfurs in some ocean-floor basalts and serpentinites. In Short Papers of the Fourth International Conference, Geochronology, Cosmochronology and Isotope Geology; Zartman, R.E., Ed.; U.S. Geological Survey: Washington, DC, USA, 1978; pp. 372-374.

56. Alard, O.; Luguet, A.; Pearson, N.J.; Griffin, W.L.; Lorand, J.P.; Gannoun, A.; Burton, K.W.; O’Reilly, S.Y. In situ Os isotopes in abyssal peridotites bridge the isotopic gap between MORBs and their source mantle. Nature 2005, 436, 1005-1008. [CrossRef] [PubMed]

57. Burton, K.W.; Schiano, P.; Birck, J.L.; Allégre, C.J. Osmium isotope disequilibrium between mantle minerals in a spinel-lherzolite. Earth Planet. Sci. Lett. 1999, 172, 311-322. [CrossRef]

58. Palmer, M.R.; Falkier, K.K.; Turekian, K.K.; Calvert, S.E. Sources of osmium isotopes in manganese nodules. Geochim. Cosmochim. Acta 1988, 52, 1197-1202. [CrossRef]

59. Martin, C.E. Osmium isotopic characteristics of mantle derived rocks. Geochim. Cosmochim. Acta 1991, 55, 1421-1434. [CrossRef] 
60. Widom, E.; Kepezhinskas, P.; Defant, M. The nature of metasomatism in the sub-arc mantle wedge: Evidence from Re-Os isotopes in Kamchatka peridotite xenoliths. Chem. Geol. 2003, 196, 283-306. [CrossRef]

61. Saha, A.; Basu, A.R.; Jacobsen, S.B.; Poreda, R.J.; Yin, Q.Z.; Yogodzinski, G.M. Slab devolatilization and Os and $\mathrm{Pb}$ mobility in the mantle wedge of the Kamchatka arc. Earth Planet. Sci. Lett. 2005, 236, 182-194. [CrossRef]

62. Stolper, E.; Newman, S. The role of water in the petrogenesis of Mariana trough magmas. Earth Planet. Sci. Lett. 1994, 121, 293-325. [CrossRef]

63. Brunelli, D.; Seyler, M.; Cipriani, A.; Ottolini, L.; Bonatti, E. Discontinuous melt extraction and weak refertilization of mantle peridotites at the Vema lithospheric section (Mid-Atlantic Ridge). J. Petrol. 2006, 47, 745-771. [CrossRef]

64. Xiong, Y.L.; Wood, S.A. Experimental determination of the solubility of $\mathrm{ReO}_{2}$ and the dominant oxidation state of rhenium in hydrothermal solutions. Chem. Geol. 1999, 158, 245-256. [CrossRef]

65. Brandon, A.D.; Becker, H.; Carlson, R.W.; Shirey, S.B. Isotopic constraints on time scales and mechanisms of slab material transport in the mantle wedge: Evidence from the Simcoe mantle xenoliths, Washington, USA. Chem. Geol. 1999, 160, 387-407. [CrossRef]

66. McInnes, B.I.A.; McBride, J.S.; Evans, N.J.; Lambert, D.D.; Andrew, A.S. Osmium isotope constraints on ore metal recycling in subduction zones. Science 1999, 286, 512-516. [CrossRef] [PubMed]

67. Büchl, A.; Brügmann, G.; Batanova, V.G.; Münker, C.; Hofmann, A.W. Melt percolation monitored by Os isotopes and HSE abundances: A case study from the mantle section of the Troodos Ophiolite. Earth Planet. Sci. Lett. 2002, 204, 385-402. [CrossRef]

68. Seyler, M.; Toplis, M.J.; Lorand, J.P.; Luguet, A.; Cannat, M. Clinopyroxene microtextures reveal incompletely extracted melts in abyssal peridotites. Geology 2001, 29, 155-158. [CrossRef]

69. Warren, J.M.; Shirey, S.B. Lead and osmium isotopic constraints on the oceanic mantle from single abyssal peridotite sulfides. Earth Planet. Sci. Lett. 2012, 359, 279-293. [CrossRef]

70. Schulte, R.F.; Schilling, M.; Anma, R.; Farquhar, J.; Horan, M.F.; Komiya, T.; Piccoli, P.M.; Pitcher, L.; Walker, R.J. Chemical and chronologic complexity in the convecting upper mantle: Evidence from the taitao ophiolite, southern Chile. Geochim. Cosmochim. Acta 2009, 73, 5793-5819. [CrossRef]

71. O’Driscoll, B.; Day, J.M.; Walker, R.J.; Daly, J.S.; McDonough, W.F.; Piccoli, P.M. Chemical heterogeneity in the upper mantle recorded by peridotites and chromitites from the Shetland Ophiolite Complex, Scotland. Earth Planet. Sci. Lett. 2012, 333, 226-237. [CrossRef]

72. Walker, R.J.; Carlson, R.W.; Shirey, S.B.; Boyd, F.R. Os, Sr, Nd, and Pb isotope systematics of southern African peridotite xenoliths: Implications for the chemical evolution of subcontinental mantle. Geochim. Cosmochim. Acta 1989, 53, 1583-1595. [CrossRef]

73. Kobayashi, K. Origin of the Palau and Yap trench-arc systems. Geophys. J. Int. 2004, 157, $1303-1315$. [CrossRef]

74. Reagan, M.K.; Heaton, D.E.; Schmitz, M.D.; Pearce, J.A.; Shervais, J.W.; Koppers, A.A. Forearc ages reveal extensive short-lived and rapid seafloor spreading following subduction initiation. Earth Planet. Sci. Lett. 2019, 506, 520-529. [CrossRef]

75. Niu, Y.; O'Hara, M.J. Global correlations of ocean ridge basalt chemistry with axial depth: A new perspective. J. Petrol. 2008, 49, 633-664. [CrossRef]

76. Suhr, G.; Kelemen, P.; Paulick, H. Microstructures in Hole 1274A peridotites, ODP Leg 209, Mid-Atlantic Ridge: Tracking the fate of melts percolating in peridotite as the lithosphere is intercepted. Geochem. Geophys. Geosyst. 2008, 9. [CrossRef]

(C) 2019 by the authors. Licensee MDPI, Basel, Switzerland. This article is an open access article distributed under the terms and conditions of the Creative Commons Attribution (CC BY) license (http://creativecommons.org/licenses/by/4.0/). 